\title{
PROGRAM IKONOGRAFICZNY WYSTROJU WNĘTRZA KOŚCIOLA PW. WNIEBOWZIĘCIA NAJŚWIĘTSZEJ MARYI PANNY I ŚW. AUGUSTYNA W KRAŚNIKU (WIEK XVII I XVIII)
}

Ikonografia sztuki powstającej w kręgu różnorodnych zgromadzeń należy do tematów rzadko podejmowanych przez polskich historyków sztuki ${ }^{1}$. Z gruntu rzeczy są to badania trudne, wymagające nie tylko typowej znajomości dziejów sztuki i ikonografii chrześcijańskiej, ale także specyficznej duchowości oraz pobożności opartej na wyjątkowym charyzmacie każdej wspólnoty zakonnej w jej kontekście historycznym, powiązanym z prawodawstwem i z losami danego zgromadzenia także w ujęciu geograficznym. Choć oparte na wieloobszarowych poszukiwaniach i analizach studia tego typu są znaczone przysłowiowym benedyktyńskim trudem przynoszą niezwykle potrzebne syntezy, w których dzieła sztuki zyskują stosowny, a często zupełnie nowy kontekst ${ }^{2}$.

Na marginesie zainteresowań historyków sztuki pozostaje kongregacja kanoników regularnych laterańskich Bożego Ciała, która formalnie powstała w 1628 roku (zatwierdzona w 1644 roku) z inicjatywy prepozyta Marcina Kłoczyńskiego i przy wydatnej pomocy biskupa Marcina Szyszkowskiego. Choć w momencie swego największego rozkwitu składała się ona $\mathrm{z}$ dwunastu klasztorów ${ }^{3}$, to do tej pory nie powstały studia całościowo ujmujące jej dorobek na niwie sztuki. Jednak

* Anna Sylwia Czyż - dr hab. historii sztuki; adiunkt w Instytucie Historii Sztuki Uniwersytetu Kardynała Stefana Wyszyńskiegow Warszawie; e-mail: aniaczyz@poczta.onet.pl

${ }^{1} \mathrm{O}$ wiele częściej podejmowane są zagadnienia związane z architekturą zakonną np.: M. Brykowska, Architektura karmelitów bosych w XVII-XVIII wieku, Warszawa 1991; K. Guttmejer, Siedemnastowieczne fundacje dla kamedułów $w$ Polsce, w: Studia nad sztuka renesansu i baroku, t. 8, cz. 3: Fundator i dzieło w sztuce nowożytnej, red. J. Lileyko, I. Rolska-Boruch, Lublin 2007, s. 55105. Zob. także publikacje Jerzego Paszendy o architekturze jezuitów w Rzeczpospolitej czy Adama Błachuta o franciszkanach reformatach.

${ }^{2}$ Najczęściej rozważania na temat ikonografii zakonnej są ograniczone do jednego kościoła. Wyjątek stanowi kompleksowe ujęcie zaprezentowane w książce A. Witko, Sztuka w stużbie zakonu Trójcy Świętej w siedemnastym i osiemnastym stuleciu, Warszawa 2002. Zob. także: J. Nowiński, Ars cisterciensis. Kościól cysterski w średniowieczu - wyposażenie i wystrój, Warszawa 2016.

${ }^{3} \mathrm{~K}$. Łatak, Kongregacja krakowska kanoników laterańskich na przestrzeni dziejów, Kraków 2002, s. 13, 36-37, 54-55, 230. 
pojedyncze opracowania czy to z zakresu historii architektury ${ }^{4}$ czy też wyposażenia świątyń kanoników regularnych laterańskich ${ }^{5}$ są wystarczającym tłem ${ }^{6}$ do podjęcia rozważań na temat ikonografii wystroju kanonickiego kościoła w Kraśniku w XVII i XVIII w. ${ }^{7}$

${ }^{4} \mathrm{~Np}$. B. Krasnowolski, Zapomniane sanktuarium maryjne i laterańskie z 1 połowy XVII wie$k u$ w Suchej. Wielka treść w skromnej formie, w: Festina lente. Prace ofiarowane Andrzejowi Fischingerowi w siedemdziesiąta rocznice urodzin, Kraków 1998, s. 127-138; Z. Bania, Architektura kościołów kanoników regularnych laterańskich ze szczególnym uwzględnieniem kongregacji Bożego Ciała na Kazimierzu w Krakowie, w: Przemijanie i trwanie. Kanonicy regularni laterańscy $w$ dawnej $i$ wspótczesnej Polsce. Materiaty z międzynarodowej konferencji zorganizowanej z okazji 600-lecia fundacji opactwa Bożego Ciała w Krakowie, Kraków 2005, s. 59-66.

${ }^{5}$ Zob. np. artykuły: Jana Samka, Jerzego Józefa Kopcia, Kazimierza Kuczmana i Wandy Morawskiej w książce Studia z dziejów kościoła Bożego Ciała w Krakowie, red. Z. Jakubowski, Kraków 1977; Pawła Dettloffa i Wacława S. Szetelnickiego w publikacji Święty Stanisław Kazimierczyk CRL (1433-1489). Postać - środowisko - kultura-dziedzictwo, red. K. Łatak, Kraków 2010; a także studia Wacława S. Szetelnickiego oraz Bogusława Krasnowolskiego w książce Klasztor Bożego Ciała Kanoników Regularnych Laterańskich w Krakowie w okresie przedtrydenckim. Ludzie - wydarzenia - budowle - kultura, red. K. Łatak, Łomianki 2012. Zob. także Z. Jakubowski, Madonna z Dzieciatkiem w krakowskim klasztorze kanoników regularnych - dzieło Lukasza Cranacha st., „Biuletyn Historii Sztuki”, 2 (1977) t. 39, s. 127-142; K. Kuczman, Italianizujące „Opłakiwanie Chrystusa” z roku 1519 w krakowskim klasztorze kanoników regularnych, „Biuletyn Historii Sztuki”, 2 (1978) t. 40, s. 104-117; a także J. Dzik, Ikonografia Stanisława Kazimierczyka jako reprezentanta światobliwych „,Felicis Saeculi Cracoviae” w polskiej sztuce nowożytnej, „Nasza Przeszłość”, 68 (1987) s. 61-91; J. Dzik, Przyczynek do mecenatu artystycznego Kościoła w XVII wieku, „Nasza Przeszłość", 75 (1991) s. 329-342; A.S. Czyż, Kościót pw. śś. Piotra i Pawła na Antokolu w Wilnie, Wrocław-Warszawa-Kraków 2008; K. Łatak, Madonna z jabluszkiem (Mater Salvatoris) w krakowskim kościele Bożego Ciała, w: Homo Creator et Receptor Artium. Ksiega pamiatkowa Księdzu Profesorowi Stanistawowi Kobielusowi ofiarowana, red. M. Wrześniak, Warszawa 2010, s. 153164; R. Rupiewicz, Pierwowzory graficzne wizerunku „Sąd nad Chrystusem” z kościoła Bożego Ciała w Krakowie, w: Inspiracje grafika europejska w sztuce nowożytnej. Czasy nowożytne, red. K. Moisan-Jabłońska, K. Ponińska, Warszawa 2010, s. 58-78; K. Latak, Z dziejów obrazu Madonny Roudnickiej w krakowskim kościele pw. Bożego Ciała, w: Architektura znaczeń. Studia ofiarowane prof. Zbigniewowi Bani w 65. rocznice urodzin i w 40-lecie pracy dydaktycznej, red. A. S. Czyż, J. Nowiński, M. Wiraszka, Warszawa 2011, s. 240-251; D. Nowacki, W sprawie kondycji badań nad tekstyliami w zbiorach krakowskich. Kapa w kościele Bożego Ciała - niedoceniony świadek potrydenckich przeobrażen kazimierskiej fary, w: Tekstylia w zbiorach sakralnych. Inwentaryzacjakonserwacja-przechowywanie, red. H. Hryszko, A. Kwaśnik-Gliwińska, M. Stachurska, Warszawa 2013, s. 165-173.

${ }^{6}$ Jako pierwszy wątki podejmowane w kościołach kanoników regularnych laterańskich wskazał Jan Samek. Według niego były to treści związane z początkiem zgromadzenia (Ordo apostolicus), pobożnością eucharystyczną (Corpus Christi) połączoną z pasyjną. Swoją tezę badacz oprał o analizę wnętrza kościoła pw. Bożego Ciała w Krakowie. Nie powiązał jednak przemian w wystroju świątyni krakowskiej w dobie nowożytnej z czasami potrydenckimi oraz duszpasterstwem prowadzonym przez kanoników regularnych. Pominął także wątek maryjny wyraźnie obecny we wnętrzach kanonickich. W niewielkim stopniu przywołał inne świątynie kanoników regularnych. J. Samek, Pozycja kościoła Bożego Ciała w sztuce Krakowa oraz jego rola w poczynaniach artystycznych kanoników regularnych kongregacji krakowskiej, w: Studia z dziejów kościoła Bożego Ciała w Krakowie, s. 21, 29-30.

${ }^{7}$ Chronologię artykułu wyznacza powstanie kongregacji Bożego Ciała i przyjęcie zasad dotyczących sztuki potrydencki przez synod krakowski oraz ostatnie nowożytne przemiany wystroju świątyni w Kraśniku u schyłku XVIII wieku. 


\section{Reforma i duchowość kanonicka a sztuka potrydencka}

Kanonicy regularni laterańscy z klasztoru Bożego Ciała jako jedni z pierwszych w Rzeczpospolitej zaczęli wcielać w życie reformy Soboru Trydenckiego, których żarliwym wyznawcą był Marcin Kłoczyński. Prepozyt krakowski odnowę związał przede wszystkim ze wzmocnieniem życia zakonnego, co wiązało się m.in. z opublikowaniem reguły oraz komentarza Piotra Clarety do konstytucji, a codzienna lektura tych aktów szybko przełożyła się na praktykę opartą o naukę, medytację, modlitwę oraz dobre działanie ${ }^{8}$.

Marcin Kłoczyński mocno akcentował wspólną modlitwę, przywracając m.in. zaniechaną praktykę dziennych i nocnych godzin brewiarzowych, a także wprowadził zwyczaj odprawiania rekolekcji. Centralnym punktem dnia uczynił mszę świętą konwentualną, w której podobnie jak w officium brewiarzowym, uczestniczyła cała wspólnota. Dopiero po niej mogły być odprawiane msze święte prywatne?

Podstawą życia duchowego kanoników regularnych było gruntowne wykształcenie. Marcin Kłoczyński dążył do odnowienia kontaktów z Akademią Krakowską, a także wysyłał współbraci na naukę na włoskie uniwersytety m.in. dzięki nawiązanym kontaktom z włoską kongregacją kanoników regularnych laterańskich. Ponadto wznowił studium wewnętrzne i zainicjował publiczne dysputy filozoficzno-teologiczne. Tradycyjnie dużą wagę przywiązywano do biblioteki i czytelnictwa ${ }^{10}$.

Działania w duchu reformy podjęto także w pozostałych klasztorach skupionych w kongregacji krakowskiej, w tym w Kraśniku, gdzie podczas kapituły generalnej w dniach 25 czerwca - 5 lipca 1635 roku uchwalono zreformowane konstytucje. Dla wspólnoty w Kraśniku szczególne znaczenie w kontekście reformy życia zakonnego miał Jan Chrzciciel Malanowski, pełniący funkcję prepozyta w latach $1628-1648^{11}$.

Kanonicy regularni, uważając się za bezpośrednich spadkobierców apostołów, nie tylko dbali o własny rozwój duchowy, ale pragnęli uświęcać innych przez szeroko zorganizowane duszpasterstwo. $Z$ jednej strony akcentowano wspólnoto-

${ }^{8}$ Mowa o Collectio super Statuta, w której Piotra Clareta wyliczał m.in. praktyki ascetyczne pomocne w osiągnięciu doskonałości: rezygnacja $\mathrm{z}$ własnej woli i całkowite zdanie się na przełożonego, umiłowanie klauzury, panowanie nad odruchami serca i językiem, cierpliwość w przeciwnościach, modlitwę, officium divinum, studium Pisma Świętego, spowiedź świętą, troskę o dobro wspólne oraz gorliwą i ofiarną posługę duszpasterską. J. B. Korolec, Biblioteki Lubelszczyzny w XV-XVIII wieku (Biblioteka Kanoników Regularnych w Kraśniku), w: Dzieje Lubelszczyzny, t. 6: Między Wschodem a Zachodem, cz. 1: Kultura umysłowa, red. J. Kłoczowski, Warszawa 1989, s. 100, 103-104; K. Łatak, S. Nalbach, Ze studiów nad kultura umystowa kanoników regularnych laterańskich krakowskiej prepozytury Bożego Ciała w XV i XVI wieku, Kraków 2009, s.103-104.

${ }^{9}$ Latak, Kongregacja krakowska, s. 36.

${ }^{10}$ Tamże, s. 36-37, 39, 74-77, 80, 87-88, 227-228; Łatak, Nalbach, Ze studiów nad kultura umystowa, s. 102-326.

${ }^{11}$ Zreformowane konstytucje obowiązywały do końca 1 . ćw. XVIII w., kiedy ponownie poddano je ożywczej dyskusji. Warto także odnotować, że kapituła generalna była zwykle odprawiana w Krakowie. W okresie nowożytnym w Kraśniku prócz 1635 zebrano się jeszcze w 1712 i 1758 roku. Łatak, Kongregacja krakowska, s. 56-59, 74-77, 80, 87-88, 108, 111; S. Więzik, Kanonicy Regularni Laterańscy w Polsce. Konstytucje kanoników regularnych laterańskich kongregacji krakowskiej dawniej i dziś, w: Przemijanie i trwanie, s. 578-579. 
wość życia, liturgię konwentualną rozumianą jako centralny punkt każdego dnia, kontemplację i pracę uświęcającą wszystkich członków zgromadzenia, a z drugiej strony realizowano się w posłudze świeckim. Podstawą duszpasterstwa, tak jak w przypadku rozwoju własnej religijności, miało być wykształcenie. Na krakowskim Kazimierzu o pobożność wiernych dbano m.in. poprzez niedzielną katechizację, którą ustanowiono za prepozytury Marcina Kłoczyńskiego. Pamiętano także o wadze religijnej lektury co przekładało się na liczne inicjatywy wydawnicze kongregacji krakowskiej. Ponadto przy każdej świątyni zakonnicy organizowali bractwa o formule maryjnej i pasyjnej, a także rozwijali kult eucharystyczny. Prowadzili także szpitale otaczając opieką potrzebujących ${ }^{12}$.

Nie inaczej było $\mathrm{w}$ Kraśniku, gdzie klasztor słyną z dobrze prowadzonej szkoły, a także ze świetnie wyposażonej biblioteki. Od 1635 roku funkcjonował przy nim nowicjat i studium retoryki. Od 1609 roku przy świątyni działało bractwo Różańcowe. Kanonicy regularni prowadzili także w Kraśniku szpita ${ }^{13}$.

Przemiany w duchowości zakonnej, a także przenikająca się zasada dbania o rozwój własny i powierzonych parafian, szła w parze $\mathrm{z}$ wykształceniem się w kręgu kanoników kongregacji krakowskiej w pierwszej połowie XVII w. świadomej działalności fundacyjnej opierającej się na nowym, kontrreformacyjnym modelu sztuki. Jej założenia sformułowano podczas Soboru Trydenckiego w dekretach uchwalonych 3 i 4 grudnia 1563 roku, a następnie zostały one rozbudowane przez teoretyków sztuki kościelnej rekrutujących się nie tylko spośród duchownych. Dla kanoników z kongregacji Bożego Ciała szczególnie ważny był twórczy ferment wśród współpracowników biskupa Marcina Szyszkowskiego. Na synodzie krakowskim zwołanym z inicjatywy hierarchy w 1621 roku zajęto się m.in. kwestiami sztuki. Nie przypadkowo po tej dacie w kościołach kongregacji krakowskiej rozpoczynają się inicjatywy artystyczne, w których dążono do całkowitego przekształcenia wnętrz w nowym duchu ${ }^{14}$. Zresztą kanonicy regularni z klasztoru Bożego Ciała w Krakowie mieli swojego teoretyka sztuki potry-

${ }^{12}$ Korolec, Biblioteki Lubelszczyzny, s. 105; Latak, Kongregacja krakowska, s. 39, 72, 79-8083,228

${ }^{13}$ Archiwum Kurii Metropolitarnej w Krakowie, AVCap. t. 44 (1637 roku), s. 32, 37; Joannis de Nigra Valle, Ord. praemonstratensis, S. R. E. Bibliothccarius In Sacri et Apostolici ordinis Canonicorum Regularium S. Augustini Congregationis S. Salvatoris, Lateranensis Genealogiam quam plurimis, iisq; gravissimis et quidem externorum authoritatibus, dilucidatus. Et per Canonicos Congregationis Cracoviensis ejusdem Instituti, vitae sanctitate, status eminentia, et doctrinae, soliditate insignes, ampliatus. Tum etiam accomodatissimis suo assumpto el intentioni Regularis Lateranensis, Schematibus exorantus nec non labore ac studio A. R. D. Aquilini Michaelis Gorczyński J. C. et S. Th. D. Canonici Regularis Laterasnensis Luci publicae reostensus. Anno Domini 1707 [bez m. dr.], s. 98 (E XVII, 243-244); Korolec, Biblioteki Lubelszczyzny, s. 99-103; Latak, Kongregacja krakowska, s. 109-110.

${ }^{14} \mathrm{~W}$. Tomkiewicz, Uchwała synodu krakowskiego z 1621 roku o malarstwie sakralnym, ,Sztuka i krytyka”, 8 (1957) s. 174-184; J. S. Pasierb, Problematyka sztuki w postanowieniach soborów, „Znak”, 12 (1964) t. 16, s. 1462-1471; P. Krasny, Visibilia signa ad pietatem excitantes. Teoria sztuki sakralnej w pismach Roberta Bellarmina, Cezarego Baroniusza, Rudolfa Hospiniana, Fryderyka Boromeusza i innych pisarzy kościelnych epoki nowożytnej, Kraków 2010, s. 8-9. W kontekście średniowiecznego wystroju kościoła pw. Bożego Ciała zob. B. Krasnowolski, Średniowieczne wnętrze kościoła Bożego Ciała w świetle kroniki ks. Stefana Ranatowicza CRL, w: Klasztor Bożego Ciała, s. $269-284$. 
denckiej, a był nim Jan Augustyn Biesiekierski, autor wydanego w 1624 roku dzieła Krótka nauka o czci i poszanowaniu obrazów świętych, który przez kilka lat był związany z Kraśnikiem ${ }^{15}$.

Za ojcami soborowymi na wspomnianym krakowskim synodzie podkreślono przede wszystkim ilustracyjny charakter sztuki kościelnej, która miała być wolna od wszelkich błędów dogmatycznych i wpływów sztuki świeckiej, a przy tym oparta na ugruntowanej tradycji przedstawień osób boskich oraz Maryi. Wizerunki świętych miały zachęcać do pobożności i oddawania czci Chrystusowi. Sztuka wprzęgnięta w nauczanie Kościoła miała stać się skuteczną bronią w walce o duszę każdego człowieka. Stąd liczyły się w niej nie tylko względy poprawności religijnej, ale przede wszystkim perswazja, oparta na emocjonalnym oddziaływaniu na zmysły. W tym kontekście estetyka zyskała nowe znaczenie, a wspaniałość architektury i wystroju świątyń miała iść w parze z ceremoniami liturgicznymi, koncentrującymi się wokół ołtarza głównego, ideowego centrum każdej świątyni ${ }^{16}$.

Tak jak dwojako rozumieli swój charyzmat kanonicy regularni laterańscy, czyli uświęcanie siebie i uświęcanie innych, tak też kreowali wystrój kościołów. Z jednej strony akcentowano wyjątkowość wspólnot kanonickich, ukazując genezę i genealogię zakonną, także w kontekście budujących przykładów postępowania. $Z$ drugiej strony koncentrowano się na ilustracyjnym przekazie skierowanym do wiernych, rozwijając równolegle wątek chrystologiczny i maryjny, wokół których organizowali działalność duszpasterską ${ }^{17}$. Zgodnie z zaleceniami potrydenckimi kanonicy regularni pragnęli, aby w świątyni i zakonnicy i świeccy znaleźli umocnienie wiary. Wokół tych dwóch przenikających się zasad kreowano wnętrze świątyni kanonickiej uwzględniając przy tym życzenia osób sprawujących nad nią opiekę patronacką, których najczęściej interesowała stosowna reprezentacja.

Przekraczając dziś próg świątyni w Kraśniku z łatwością można odnaleźć cztery historyczne wątki treściowe: kanonicki, pasyjno-eucharystyczny oraz maryjny, a także patronacki ${ }^{18}$. Przy czym program wnętrza został określony jeszcze

${ }^{15}$ Latak, Kongregacja krakowska, s. 109; Krasny, Visibilia signa, s. 7, 186-189.

${ }^{16}$ Pasierb, Problematyka sztuki, s. 1463-1464, 1471-1476; M. Kaleciński, Muta praedicatio. Studia z historii i recepcji malarstwa wtoskiego doby potrydenckiej, Warszawa 1999, s. 13-30; Krasny, Visibilia signa, s. 40-41, 44-51, 70-71.

${ }^{17}$ Zob. uwagi na temat działalności duszpasterskiej zakonników w Kraśniku: Korolec, Biblioteki Lubelszczyzny, s. 105-106.

${ }^{18} \mathrm{~W}$ niniejszym artykule wątek patronacki zostanie potraktowany marginalnie ze względu na chęć wyeksponowania specyfiki wnętrz kościołów kanoników regularnych laterańskich. Niemniej należy podkreślić ogromną wagę herbów Topór, Pilawa, Strzemię, Korczak, Jelita, i Leliwa, które zdobią gotyckie sklepienie kościoła, a także znajdują się na szesnastowiecznych portalach, parapecie chóru muzycznego i bramce ambony. Tworzą one symboliczną galerię patronów kościoła i klasztoru, którzy rekrutowali się z okolicznych szlacheckich rodów. Za Jerzym Kowalczykiem należy podkreślić ogromną wagę heraldyki wprowadzanej we wnętrzu świątyni także za czasów Tomasza Zamoyskiego. Szczególne miejsce zajął ołtarz główny, gdzie wbrew zaleceniom Soboru Trydenckiego pojawiły się herby (m.in. Korczak Gorajskich, Topór Tęczyńskich, Rawicz legendarnych założycieli miasta Kraśnickich). Zamoyski chciał w ten sposób wpisać się w tradycję opieki nad kościołem w Kraśniku, jaki sprawowali kolejni właściciele miasta. Było to także włącznie się w tradycje starych rodów szlacheckich, które Kraśnik trzymały i możliwość powiązania stosunkowo młodego rodu senatorskiego (drugie pokolenie Zamoyskich) ze starszymi. J. Kowalczyk, Koronacja Najświętszej Maryi Panny w Kraśniku - dzieło Jana Kasińskiego, „Rocz- 
w latach 30. XVII w. Wraz ze zmieniającymi się modami artystycznymi oraz oczekiwaniami i wiernych i samych kanoników w drugiej połowie XVIII w. program oparty o te same schematy treściowe został w Kraśniku uzupełniony w nowej szacie stylowej. U schyłku osiemnastego stulecia wnętrze świątyni zaczęło tracić swą kanonicką wyjątkowość na rzecz uniwersalizmu kościelnej ikonografii $^{19}$.

\section{Ordo apostolicus i jego patroni}

Kanonicy regularni laterańscy tworzyli wspólnoty na podobieństwo zgromadzenia dwunastu apostołów. W ten sposób nie tylko, jak wszyscy kapłani wskazywali na posługę rozumianą jako kontynuowanie dzieła Chrystusa, ale przede wszystkim podkreślali genezę swego zakonu. Nie bez przyczyny nazywali je „ordo apostolicus”20. Byli bowiem przekonani, że zostało ono założone przez apostołów według zaleceń samego Chrystusa ${ }^{21}$. O zgromadzeniu kanoników regularnych mówiono jako o „zakonie świętym apostolskim [...] od samych apostołów całe osiem set lat [służącym, wtrącenie A. S. Czyż] Bogu w laterańskim arcypatriarchalnym kościele"22. Natomiast styl życia zakonników „,reguły apostolskiej”23 miał odzwierciedlać sposób działania uczniów Chrystusa. Nawet ubiór kanoni-

niki Humanistyczne", 42 (1994) s. 139; R. Karpińska, Z kart historii miasta i kościoła, w: Kościół Wniebowzięcia Najświętszej Maryi Panny w Kraśniku, Kraśnik 2013, s. 16-18.

${ }^{19}$ Widać to szczególnie w ikonografii sześciu ołtarzy bocznych, które powstały w 1792 roku. Przy łuku tęczowym są to ołtarze: Swiętej Anny Samotrzeć (w zwieńczeniu znajduje się obraz Matka Boska ze św. Janem Chrzcicielem; patrocinium notowane w 1689 roku, AKMK, AV Cap., t. 66, s. 50, 53) oraz Serca Pana Jezusa z obrazem z 1952 roku (w zwieńczeniu Komunia św. Marii Egipcjanki). Kolejne dwa poświecono św. Antoniemu Padewskiemu i św. Franciszkowi oraz św. Józefowi (na zasuwie obraz św. Mikołaja) i św. Szymonowi. Od strony kruchty znajdują się ołtarze św. Mikołaja i św. Floriana oraz św. Marii Magdaleny i św. Wawrzyńca (pierwotnie zapewne wspomniany wyżej wizerunek Komunii św. Marii Egipcjanki). Przy tym ostatnim ołtarzu, którego patrocinium zanotowano podczas wizytacji w 1689 roku sprawowano msze święte za zmarłych kanoników regularnych laterańskich. Fakt ten łączy się z postrzeganiem świętej jako patronki dobrej śmierci. AKMK, AV Cap., t. 66 (1689), s. 50; K. Moisan-Jabłońska, Obrazowanie walki dobra ze złem, Kraków 2002, s. 196-198.

${ }^{20}$ Łatak, Kongregacja krakowska, s. 72; Samek, Pozycja kościoła, s. 29; H. D. Wojtyska, Duchowość kanoników regularnych, „Saeculum Christianum”, 1 (1996) t. 3, s. 127.

${ }^{21} \dot{Z}$ ywot, sprawy y cudowne Boskie wstawienie pobożnego Kapłana B. Stanistawa Kazimirczyka, przy Krakowie na Kazimirzu u Bożego Ciała, Congrcgacyey Zbawicielowey: Kanoników z Literanu wedlug Reguly S. Angustyna ... Ku chwale Bożey y czci Świętych iego ... dopiro teraz Polskim ięzykiem napisany, dostateczniey y własniey niżeli byt przed tym po Łacinie wydany $w$ roku 1609 przez X. Krzysztofa Łoniewskiego, tegoż Conwentu Kanonika. Z dozwoleniem Starszych. W Krakowie, w drukarniey Lazarzowey, Maciey Jędrzeiowczyk drukowat Roku P. 1617, s. 12-14 (E XXI, 399).

${ }^{22}$ Tamże, s. 25; zob. także: Wieniec przezacnemu w Kościele Bożym ... s. Augustynowi od ks. Jacka Liberiusza ... proboszczowi kościoła Bożego Ciała ... uwity. W Krakowie w drukarni wdowy Łukasza Kupisza ... Roku Pańskiego 1644, s. 25 (E XXI, 262); K. Łatak, Kanonicy regularni laterańscy na Kazimierzu w Krakowie do końca XVI wieku, Ełk 1999, s. 194.

${ }^{23}$ Wieniec, s. 25. Według Possydiusza z Kalamy, biografa św. Augustyna, wspólnota w Hipponie posługiwała się zasadami ustalonymi przez apostołów. Wzorem dla niej była gmina jerozolimska opisana w Dziejach Apostolskich (Dz 4, 32-34). Possydiusz z Kalamy, Żywot św. Augustyna, thum. P. Nehring, Kraków 2002, s. 59. Zob. Łatak, Kanonicy, s. 16-17. 
ków regularnych był typu „odzienia apostolskiego z mozettami abo almucjami $\mathrm{i}$ inszym habitem [...] z biskupy [...] rokiety abo komże"24, uświęconym przez samego Zbawiciela ${ }^{25}$.

Stąd nie dziwi, że w dekoracji kościołów kanoników regularnych laterańskich obowiązkowo musiały pojawić się wizerunki apostołów, pierwszych członków zgromadzenia ${ }^{26}$. W świątyni w Kraśniku na początki wspólnot kanonickich wskazują malowane postaci uczniów Chrystusa ponad arkadami nawy głównej, które być może pojawiły się w tym miejscu już w latach 30 . XVII w. Apostołowie to strażnicy bram Niebiańskiego Jeruzalem, a ich poczet od ołtarza głównego otwierają św. Piotr (od południa) i św. Paweł (od północy). Wyróżnienie książąt Kościoła oraz wprowadzenie kolegium apostolskiego stanowi wykładnię katolickiej wiary i ilustrację Składu Apostolskiego. Przedstawienie ich ponad arkadami to także jasna aluzja do postrzegania apostołów jako filarów Kościoła ${ }^{27}$.

Niebagatelną rolę w dziejach kanoników regularnych odegrał św. Augustyn, który stał się prawodawcą i pierwszym reformatorem zakonnym, co tłumaczono następująco: „na początku Kościoła Pańskiego za apostołów i długo po tym wszystko duchowieństwo żyło wspólnie na kształt zakonników, osobliwie przy kościołach katedralnych pod biskupami. Pilno ta społeczność życia chowali, majętność mieli wspólne, stół wspólny [...]. Lecz gdy za czasy miłość Boża w sercach ludzkich poczęła stygnąć [...] Augustyn święty chcąc wzbudzić on porządek życia apostolskiego reformował przy katedrze swojej kanoniki i kapłany i napisał regulę" 28 .

Odwołanie w tradycji zakonnej do wczesnochrześcijańskich wspólnot formujących się przy biskupach spowodowało, że kanonicy regularni uważali ich

${ }^{24}$ Żywot, sprawy y cudowne Boskie wstawienie pobożnego Kapłana B. Stanisława Kazimirczy$k a$, s. 18. O apostolskich początkach zgromadzenia rozkwitającego w czasach wczesnego chrześcijaństwa zob. Joannis de Nigra Valle, s. 1-3; Krótka nauka o czci i poszanowaniu obrazów Swiętych, przydane opisanie obrazu Najśw. P. Maryi w kaplicy kościoła Ciała Bożego Wielebnych Ojców Kanoników laterańskich Augustyna S. na Kazimierzu przy Krakowie .... przez W. X. Jana Augustyna Biesiekierskiego Kanonika laterańskiego S. Augustyna Zakonu. Za dozwoleniem Starszych. W Krakowie w Drukarni Macieja Andrzejowczyka R. P. 1624, k. 23v-24 (E XIII, 96).

${ }^{25}$ Krótka nauka, k. 25v.

${ }^{26}$ W kościele pw. Bożego Ciała w Krakowie do początku XVII w. znajdował się ołtarz Apostołów, a na zlecenie ks. Marcina Kłoczyńskiego Tomasz Dolabella namalował w 1627 roku płótno zatytułowane Ordo Apostolorum. Kolegium apostolskie w formie stiukowych figur umieszczono w niszach nawy kościoła pw. śś. Piotra i Pawła na Antokolu w Wilnie. Przedstawienia takie były popularne także w klasztorach kanoników nie wchodzących w skład kongregacji krakowskiej. W kościele w Czerwińsku ukazano ich w apsydzie prezbiterium (30. XVI w.). Na siedemnastowiecznej ambonie w świątyni w Krzepicach na Śląsku (pow. kłobucki) ukazano figury dwunastu apostołów, co jest dość rzadkim przykładem w dekoracji ambon. K. Kuczman, Tomasza Dolabelli „Pokłon pasterzy”, w: Studia z dziejów, s. 51; Samek, Pozycja kościoła, s. 29-30; Czyż, Kościót pw. śś. Piotra i Pawta, s. 231; Dzik, Ikonografia, s. 72-73; Łatak, Kanonicy, s. 98, 100, 118-119.

${ }^{27}$ R. Knapiński, Credo Apostolorum w średniowiecznej i nowożytnej ikonografii kościelnej, w: Symbol Apostolski w nauczaniu i sztuce Kościoła do soboru trydenckiego, red. R. Knapiński, Lublin 1997, s. 331-332, 336, 338-340, 352, 354; S. Kobielus, Concordia Novi et Veteris Testamenti. Zapowiedzi dzieła odkupienia i jego spetnienie w teologii i sztuce średniowiecza, Poznań 2013, s. $161-162$.

${ }^{28}$ Wieniec, s. 24-25. 
członków za przedstawicieli swego zgromadzenia. Napawało to zakonników niekłamaną dumą, bowiem ponownie udowadniano w ten sposób „pierwszeństwo” zgromadzenia, które ozdobione było męczennikami i wyznawcami wczesnego chrześcijaństwa i świętymi rekrutującymi się z biskupów tego chwalebnego cza$\mathrm{su}^{29}$. Sięgnięcie do tak odległej historii było przy tym świadectwem nieprzerwanego trwania przy Kościele rzymskim, a także wyraźnym znakiem o wymowie antyprotestanckiej opartym na podkreśleniu tradycji, co nie było przypadkowe szczególnie na Lubelszczyźnie, gdzie swą obecność silnie zaznaczały religie protestanckie. Propagowanie „antyku chrześcijańskiego” było dla zakonników źródłem tożsamości i wpisywało się w przemiany duchowości powiązanej z Soborem Trydenckim ${ }^{30}$.

Do najdawniejszych dziejów zgromadzenia poprzez wskazanie budujących przykładów świętych z niego się wywodzących nawiązuje dekoracja dwurzędowych stalli kanonickich (ok. $1630^{31}$ ). Na dwunastu zapleckach umieszczono wizerunki świętych kanoników regularnych, którym odpowiadają sceny w zwieńczeniu z historią św. Augustyna i św. Moniki ${ }^{32}$. Na zapleckach stall po stronie północnej ukazano: Romana ${ }^{33}$, Klemensa Aleksandryjskiego ${ }^{34}$, Hadriana ${ }^{35}$, Papiniana

29 „Idąc od samych apostołów i napierwszym będąc [zakonem] w Kościele Bożym ma z pośrzodku siebie niemało papieżów, siłu kardynałów, a świętych barzo wiele. [...] [Od] samego Leona pierwszego liczy papieżów trzydzieści i sześć". Wieniec, s. 25. Zob. także Joannis de Nigra Valle, s. 4, 17-22; Krótka nauka, k. 25v.

${ }^{30}$ Krasny, Visibilia signa, s. 29-34.

${ }^{31} \mathrm{Na}$ stallach, przede wszystkim w pierwszym rzędzie, znajdują się różnorodne napisy wykonane przez samych kanoników regularnych, z których najstarszy powstał jeszcze w 1545 roku. Można zatem założyć, że nowe stalle zostały ok. 1630 roku zestawione ze starszymi sediliami oraz policzkami, których formę można datować na 2 ćw. XVI w. Katalog zabytków sztuki w Polsce, t. 8: Województwo lubelskie, red. R Brykowski, E. Smulikowska, Z. Winiarz, z. 9: Powiat kraśnicki, oprac. J. Galicka, E. Smulikowska, Warszawa 1961 (dalej Katalog zabytków), s. 18 (tu data 1. ćw. XVII w.); J. Samek, Polskie rzemiosto artystyczne. Czasy nowożytne, Warszawa 1984, s. 154 (tu data 1614-1620).

${ }^{32}$ W Katalogu zabytków (s. 18) błędnie podano, że są to sceny z życia kanoników.

${ }^{33}$ Diakon Roman z Cezarei (III/IV w.), który podczas prześladowania za czasów Galeriusza znalazł się w Antiochii. Podtrzymywał chrześcijan w wierze za co został skazany na spalenie. Wobec jego nieustępliwości przyprowadzono go przed cesarza i odcięto mu język. Joannis de Nigra Valle, s. 55; M. Wysocki, Roman z Cezarei, w: Encyklopedia Katolicka (dalej EK), t. 17, kol. 258.

${ }^{34}$ Ojciec Kościoła (ok. 150 - przed 215) piszący po grecku, założyciel aleksandryjskiej szkoły teologicznej. Jego najsłynniejszym dziełem są „Kobierce”, stąd w Kraśniku trzyma w dłoniach księgę z napisem: „Libri octo de stromatibus”. Joannis de Nigra Valle, s. 49; F. Drączkowski, Klemens Aleksandryjski, EK, t. 9, kol. 98-102.

${ }^{35}$ Zapewne jest to Hadrian z Cezarei, który podczas prześladowania w 309 roku zginął ścięty mieczem. Wizerunkowi towarzyszy napis: „Unus trinus verus Deus”. Zob. także Joannis de Nigra Valle, s. 55, gdzie notowany jest męczennik o tym samym imieniu, który miał zginąć za Genzeryka. 
i Mansweta $z$ towarzyszami ${ }^{36}$, Marcelina ${ }^{37}$ oraz Gelazego ${ }^{38}$. Po południowej stronie są to: Prosper z Akwitaniii ${ }^{39}$, Cerboniusz ${ }^{40}$, Patryk ${ }^{41}$, Trudon ${ }^{42}$, Teodoryk ${ }^{43}$ oraz męczennicy z Anglii ${ }^{44}$.

Przedstawicieli świętych kanoników wybrano w kluczu dawności zgromadzenia, jedyny wyjątek czyniąc dla męczenników z Anglii, którzy zginęli w 1572 roku podczas zaprowadzania reformacji ${ }^{45}$. Ważne było też wskazanie na świętych

${ }^{36}$ Papinian z Wity i Manswet z Uruci to biskupi afrykańscy, którzy wraz z towarzyszami zginęli w czasach, gdy Wandalowie pod wodzą Genzeryka zajęli Rzym w 429 roku. Obaj hierarchowie trzymają wizerunek Maryi w typie Salus Populi Romani, powyżej którego znajduje się napis: „Domina Nostra". Joannis de Nigra Valle, s. 36, 55; H. Fros, F. Sowa, Księga imion i świętych, Kraków 2000, t. 4, szp. 505; W Katalog zabytków (s. 18) błędnie podano imię jednego z biskupów: Mansuez.

${ }^{37}$ Pracował jako misjonarz we Fryzji. Uleczył dwóch chorych na trąd przed bramą klasztoru. $\mathrm{Na}$ wizerunku z Kraśnika towarzyszy mu banderola z napisem „Coronaberis”. Joannis de Nigra Valle, s. 56-57, 59.

${ }^{38}$ Św. Gelazemu I (zm. 496) przypisuje się sformułowanie dogmatu o grzechu pierworodnym. Przedstawiono więc go, gdy zwraca się do Maryi: „Offer Filio Beatissima Mater et Virgo”. Był także zaangażowany $\mathrm{w}$ walkę $\mathrm{z}$ herezjami $\mathrm{i}$ opowiadał się za prymatem papieskim, określił zasady stosunku władzy świeckiej i duchowej. Joannis de Nigra Valle, s. 46; F. Drączkowski, Gelazy I, EK, t. 5, kol. 932.

${ }^{39}$ Św. Prosper z Akwitanii (ok. 390-ok. 455) członek klasztoru w Marsylii, walczył z herezjami. Wymieniał listy ze św. Augustynem. Z czasem osiedlił się w Rzymie, gdzie był sekretarzem Leona Wielkiego. J. M. Szymusiak, M. Starowieyski, Stownik wczesnochrześcijańskiego piśmiennictwa, Poznań 1971, s. 333-335. Na wizerunku znajduje się otwarta księga z napisem: „Deus meus et omnia; Iesus Maria, amores mei dulcissimi, moria ego, patiar ego, amore vestri: totus sim vester, et nemo meus", który święty zdaje się przepisywać. Jest to cytat zaczerpnięty ze słów przypisywanych jezuicie św. Alfonsowi Rodriguezowi (1533-1617).

${ }^{40}$ Biskup z Populonii (Massa Marittima) zmarły ok. 575 roku. Kaplica dedykowana św. Cerboniuszowi znajduje się w kościele pw. śś. Piotra i Pawła na Antokolu w Wilnie. Przedstawiono go także na zapleckach stall w kościele pw. Bożego Ciała w Krakowie. W. Morawska, Obrazy w stallach kościoła Bożego Ciała, w: Studia z dziejów, s. 74-75, 101; Czyż, Kościół pw. śś. Piotra i Pawta, s. 240.

${ }^{41}$ Biskup i apostoł Irlandii (ok. 416-493) czczony w środowisku kanoników regularnych laterańskich. Przedstawiono go także na zapleckach stall w kościele pw. Bożego Ciała w Krakowie. Morawska, Obrazy w stallach, s. 65; R. Prejs, M. Siodłowska, Patryk, EK, t. 15, kol. 63-64.

${ }^{42}$ Św. Trudon (ok. 630-ok. 695) urodził się w Hesbaye, w Limburgii belgijskiej. Pobierał nauki u św. Remakla, a potem u biskupa Metzu Klodulfa. Ok. 655 roku otrzymał święcenia kapłańskie, a następnie wrócił do rodzinnej posiadłości Sarchinium (Sint-Truiden), gdzie wybudował kościół i klasztor. Joannis de Nigra Valle, s. 43, 59; Fros, Sowa, Księga imion i świętych, t. 5, kol. 549. Święty wypowiada słowa: „Ad te levavi oculos meos qui habitas in caelis”, co jest fragmentem zaczerpniętym z Psalmu 122, 1.

${ }^{43}$ Jest to zapewne św. Teodoryk (zm. 1022), który pochodził z rodziny możnowładców i był spokrewniony z królową Konstancją, żoną Roberta II Pobożnego. Wstąpił do benedyktynów, a ok. 1016 roku został biskupem Orleanu. Pod koniec życia osiadł w klasztorze w Sens. Pochowany został w klasztorze Saint-Michele de Tonnerre. A. Kołtunowska, Teodoryk, EK, t. 19, kol. 630. Na portrecie św. Teodoryka w Kraśniku znajduje się stolik z otwartą książką z napisem „A Domino factum est istud et est mirabile in oculis nostris Psalm 117" (wers 23).

${ }^{44}$ Przedstawieniu towarzyszy banderola z napisem: „Martyres Domini Dominum benedicte in aeternum”, zaczerpniętym z oficjum brewiarzowego „Commune Plurimorum Martyrum” (Breviarium Romanum ex decreto Sacrosancti Concilii Tridentini restitutum..., [b. m.] 1774, s. XLVI). Męczenników z Anglii ukazano m.in. w stallach w kościele pw. Bożego Ciała w Krakowie. W. Morawska, Obrazy w stallach, s. 80-81; Łatak, Kanonicy, s. 149-150.

${ }^{45}$ Być może w kontekście tym pojawił się także św. Teodoryk, który zmarł co prawda w XI 
wywodzących się spośród biskupów (Cerboniusz, Patryk), wśród których znalazł się także biskup Rzymu Gelazy I. Związki ze Stolicą Piotrową podkreślają także Papinian i Manswet oraz ich towarzysze - męczennicy z czasów zajęcia Rzymu przez Wandali, którzy nieprzypadkowo niosą wizerunek Salus Populi Romani (Ocalenie Ludu Rzymskiego), bowiem Maryję Śnieżną czczono także w Kraśni$\mathrm{ku}$. Wyeksponowano również uczonych teologów biorących udział w dysputach dogmatycznych wczesnego chrześcijaństwa (Prosper Akwitanus, Klemens Aleksandryjski, Gelazy I) oraz misjonarzy (Marcelin) i męczenników (Roman, Hadrian).

W większości byli to święci niezbyt znani, także w środowisku samych kanoników regularnych, stąd przedstawieniom towarzyszą rozbudowane inskrypcje, a także dodatkowe napisy na księgach lub też na banderolach mające za zadanie dookreślić daną osobę (np. Klemensowi Aleksandryjskiemu towarzyszy napis na księdze odwołujący się do jego najsłynniejszego dzieła „Kobierce”), również w kontekście duchowości (np. przy wizerunku Papiniana i Mansweta „Domina Nostra"). Podczas trudności z odnalezieniem właściwych słów, które mogli by wypowiadać święci kanonicy posługiwano się cytatami z powszechnie wówczas znanych Psalmów (np. Trudon, Teodoryk) lub też z pism innych świętych (np. Prosper Akwitana zdaje się przepisywać słowa ułożone przez jezuitę św. Alfonsa Rodrigueza), albo też odwołano się do myśli teologicznej św. Augustyna (np. Hadrianowi z Cezarei towarzyszy napis „Unus trinus verus Deus”).

Nie uniknięto przy tym błędów faktograficznych podanych w objaśnieniach czy też w sposobie ukazania poszczególnych postaci (np. Prosper Akwitana działał w czasach Leona Wielkiego a nie Gelazego I, a Klemens Aleksandryjski nie był kardynałem ${ }^{46}$ ). Jednak owe nieścisłości, o ile nawet twórcy programu ikonograficznego stall byli ich świadomi, nie przeszkadzały w wyraźnym podkreśleniu dawności i niezwykłości zgromadzenia kanoników regularnych. Wizerunki świętych były też dla zakonników właściwymi wzorcami codziennej, praktycznej pobożności opartej o naukę i modlitwę oraz o heroiczną i bezkompromisową posługę duszpasterską.

Wydźwięk wzorca kontynuowały w zwieńczeniu stall sceny z życia św. Augustyna oparte o „Wyznania” oraz biografię autorstwa Possydiusza z Kalamy, w których ważne miejsce zajęła św. Monika ${ }^{47}$. W życiorysie świętego prawodawcy wyraźnie podkreślono naukę, nawrócenie oraz modlitwę, co przełożyło się na dobrą śmierć wyobrażoną poprzez jego pogrzeb. Zarówno wizerunki w zapleckach jak i sceny z życia św. Augustyna były więc ilustracją zalecanej przez Piotra Claretę

wieku, ale jego zwłoki wystawione w relikwiarzu zostały sprofanowane podczas niepokojów religijnych we Francji w 1568 roku. W 1611 roku ponownie wystawiono je dla wiernych. Zob. wyżej.

${ }^{46}$ Tak go określali sami kanonicy. Zob. Joannis de Nigra Valle, s. 49.

${ }^{47}$ Obrazy zostały przemieszczone. Gdyby układać sceny chronologicznie miałyby następujący porządek: Św. Augustyn podczas nauki w szkole w Tagaste, Pożegnanie z matka przed podróża, Modlitwa św. Moniki, Katecheza św. Augustyna, Tolle lege, Chrzest św. Augustyna, Pogrzeb św. Moniki, Św. Augustyn ze wspólnota w Hipponie, Konsekracja na biskupa Hippony, Pogrzeb św. Augustyna. Jako pierwsze/ostatnie byłyby obrazy: św. Monika przed krzyżem oraz Dzieciatko Jezus przebijajace strzała miłości Bożej serce św. Augustyna. Zob. Św. Augustyn, Wyznania, thum. Z. Kubiak, Kraków 1996; Possydiusz z Kalamy, Żywot św. Augustyna. 
„reformy człowieka wewnętrznego” poprzez życie wspólnotowe, modlitwę, wyrzeczenia i działanie dla dobra bliźniego ${ }^{48}$.

Osoba prawodawcy zgromadzenia - św. Augustyna, którego wspomnienie 28 sierpnia zakonnicy traktowali jako święto własne, była przez nich otaczana ogromną czcią ${ }^{49}$. Wizerunki biskupa z Hippony w stroju kanoników regularnych laterańskich można oglądać w kościele w Kraśniku wielokrotnie. Przestawiano go przy tym albo samodzielnie (obrazy) lub też w towarzystwie innych świętych najczęściej ojców Kościoła (stalle, ołtarze), zarówno w realizacjach malarskich jak i rzeźbiarskich. Doskonałym przykładem mogą być stalle kolatorskie Tomasza Zamoyskiego i Katarzyny z Ostrogskich stojące w prezbiterium (lata 30. XVII w. $)^{50}$, gdzie na zaplecku ukazano św. Augustyna, kiedy zwraca się ku Trójcy Świętej (il. 1). Przy tym należy podkreślić, że przedstawiono go w stroju kanonickim ${ }^{51}$. Jedynym elementem odnoszącym się do jego biskupiej godności jest podtrzymywany przez anioła pastorał oraz infuła znajdująca się na pulpicie tuż obok księgi ${ }^{52}$. $\mathrm{Z}$ kolei atrybut w dłoniach świętego prawodawcy odnosi się do popularnej, lecz apokryficznej historii, kiedy to miał doświadczyć wizji Matki Boskiej z Dzieciątkiem Jezus, które trzymając w dłoniach łuk mierzyło w jego kierunku. Serce św. Augustyna zostało wówczas przeszyte strzałą miłości Bożej, a płonąc stało się „niebieską pochodnią"53. Scenę tę w kościele w Kraśniku przedstawiono i na jednym z obrazów w zwieńczeniu stall kanonickich i w predelli ołtarza bractwa Różańcowego.

W świątyni kraśnickiej musiały także funkcjonować ołtarze boczne dedykowane św. Augustynowi i św. Monice, czego nie udało się potwierdzić w źródłach

${ }^{48}$ Korolec, Biblioteki Lubelszczyzny, s. 103; Łatak, Kanonicy, s. 153, 194-195, 200-201, 273; Łatak, Kongregacja krakowska, s. 72, 79; H. D. Wojtyska, Czytelnictwo i biblioteki u kanoników regularnych laterańskich kongregacji Bożego Ciała, w: Kanonicy regularni laterańscy w Polsce. Studia z dziejów kongregacji krakowskiej XV-XIX w., red. Z. Jakubowski, Kraków 1975, s. 54, 56-57; H. D. Wojtyska, Nauka i nauczanie u kanoników regularnych (na przykładzie Kongregacji Bożego Ciała), w: Dzieje teologii katolickiej w Polsce, red. M. Rechowicz, Lublin 1975, t. 2, z. 2, s. 491; Wojtyska, Duchowość kanoników, s. 128-130.

${ }^{49}$ W Polsce obchodzono je także 23 VIII. Łatak, Kongregacja krakowska, s. 76, 199; Moisan-Jabłońska, Obrazowanie walki, s. 249-250.

${ }^{50}$ Stalle w Katalogu zabytków (s. 18) datowane są na 1. ćw. XVII w. Ze względu na obecność ornamentu chrząstkowo-małżowinowego wydaje się, że datację należy przesunąć na lata 30 . XVII w. Samek, Polskie rzemiosto, s. 154 (tu data 2 ćw. XVII w.).

${ }^{51}$ Wśród zgromadzeń posługujących się regułą św. Augustyna było powszechnym zwyczajem, że prawodawcę przedstawiano $\mathrm{w}$ habicie zakonnym. W ten sposób podkreślano związek ze świętym i jednoznacznie wskazywano na genealogię zgromadzenia. J. B. Knipping, Iconography of the Counter Reformation in the Netherlands. Heaven on Earth, Nieuwkoop-Leiden 1974, t. 1, s. 166.

${ }^{52} \mathrm{~W}$ dolnej części wizerunku znajduje się napis: „Magnificate Dominum Meum”, co jest parafrazą modlitwy Maryi wypowiedzianej podczas spotkania ze św. Elżbietą. Cytat winien brzmieć: „Magnificat anima mea Dominum” (Łk 1, 46). Druga z inskrypcji na obrazie „Nolo solus magnificare nolo solus amare", stanowi fragment z komentarza do Psalmu 33 autorstwa św. Augustyna. Patrologia Latina, t. 36, s. 311. Cytaty biblijne oparto na Wulgacie Klementyńskiej („Biblia sacra juxta Vulgatam Clementinum" wydanie elektroniczne http://vulsearch.sourceforge.net/index.html).

${ }^{53}$ Gorejące serce ilustruje miłość św. Augustyna do Boga i tęsknotę za Nim. Wieniec, s. 27; Knipping, Iconography of the Counter Reformation, t. 1, s. 98, 166; K. S. Moisan, Matka Boska Pocieszenia, w: Maryja orędowniczka wiernych, red. J. S. Pasierb, Warszawa 1987, s. 137; Moisan-Jabłońska, Walka dobra, s. 245, 253. 
archiwalnych. Jednak wskazuje na to para obrazów z 1627 roku jakie wiszą obecnie w nawach bocznych. I syna i matkę przedstawiono podczas modlitwy, kiedy to widzą odpowiednio Trójcę Świętą oraz Maryję z Dzieciątkiem Jezus. Inskrypcje na obrazach odwołują się do umiłowania Chrystusa oraz do nawrócenia ${ }^{54}$.

Eksponowanie we wnętrzu świątyni św. Moniki nie jest przypadkowe. Przez pokrewieństwo krwi i rolę jaką odegrała w życiu biskupa Hippony kanonicy regularni laterańscy postrzegali ją jako swoją patronkę ${ }^{55}$. Św. Monikę ukazano w Kraśniku i na obrazach i w rzeźbach ołtarza głównego i brackiego w stroju mniszki, kiedy oddaje się modlitwie przez co stawała się dla zakonników wzorem pobożności zgodnie ze słowami św. Augustyna „Trwajcie na modlitwie"

O św. Augustynie i św. Monice nie zapominano także w XVIII w., kiedy wykonano dekorację malarską prezbiterium. Ukazano ich na łuku tęczowym od strony ołtarza głównego w scenie (il. 2), kiedy to Matka Boska Pocieszenia, orędowniczka dusz czyśćcowych, ofiarowuje im pasek mający być wybawieniem dla cierpiących $^{57}$.

Kult Matki Boskiej Pocieszenia wiąże się ściśle z zakonem augustianów eremitów. Przez braterstwo reguły i sąsiedztwo kościołów na krakowskim Kazimierzu sięgnęli do niego także kanonicy regularni laterańscy. Ikonografia oparta jest na wizji św. Moniki, która po śmierci męża prosiła Maryję, aby wskazała jej strój, w jakim Bogurodzica chodziła po ukrzyżowaniu Syna. Najświętsza Panna nakazała świętej wybrać długą czarną suknię przepasaną rzemieniem. Przy czym wierzono, że pasek, który mogli nosić także wierni, bronił duszę i ciało od grzechów głównych, był widzialnym znakiem miłości do Maryi, ale też sposobem, poprzez który czyniła cuda. Moc paska roztaczała się także na dusze czyśćcowe, wyobrażone także w Kraśniku (il. 2), stając się łącznikiem między Kościołem Triumfującym a cierpiącym. W związku z tym, że malowidło w Kraśniku znajduje się od strony prezbiterium i było niewidoczne dla wiernych, można założyć że

\footnotetext{
${ }^{54}$ Św. Augustyna ukazano w kontekście jego rozważań nad teologią Trójcy Świętej oraz apokryficznej wizji serca świętego przeszytego miłością Bożą, na co wskazuje napis wychodzący z ust ojca Kościoła: „Percussisti cor meum verbo tuo Domine quasi sagitta acuta”, który jest przetworzeniem fragmentu zaczerpniętego z „Wyznań”. Patrologia Latina, t. 32, s. 782. Inskrypcja na obrazie św. Moniki informuje, że ukazano ją kiedy dziękuje za nawrócenie syna. Przy tym jej słowa „Convertisti planctum meum in gaudium mihi" zostały zaczerpnięte z Psalmu 29, 12. Anioł na wizerunku ze św. Moniką trzyma banderolę z napisem: „Propter tuas lachrymas non peribit filius tuus”. Warto także podkreślić, że w kontekście symbolu nawrócenia i życia konsekrowanego postrzegali kanonicy regularni laterańscy św. Marię Magdalenę, której dedykowano jeden z ołtarzy bocznych. Tym chętniej wizerunki świętej umieszczali w swoich kościołach, że nazywano ją także apostołką apostołów. Łatak, Kanonicy, s. 200; Czyż, Kościól pw. śs. Piotra i Pawła, s. 239.

${ }^{55}$ P. Nehring, Wstęp. Św. Augustyn - asceta, mnich, biskup, w: Św. Augustyn, Pisma monastyczne, tłum. P. Nehring, M. Starowieyski, R. Szaszka, Kraków 2002, s. 33, 39, 42; Moisan, Matka Boska Pocieszenia, s. 135. W kościele pw. śś. Piotra i Pawła na Antokolu w Wilnie jedną z kaplic poświecono św. Monice, a w ołtarzu prezentowany jest jej wizerunek w stroju mniszym. Czyż, Kościót pw. śś. Piotra i Pawła, s. 236-237.

${ }^{56}$ Reguła św. Augustyna. Ordo monasterii i Praeceptum, thum. M. Starowieyski, w: Św. Augustyn, Pisma, s. 157. Zob. także C. Ripa, Iconologia, Kraków 2002, s. 134, 289-290; Łatak, Kongregacja krakowska, s. 74-77, 79; Wojtyska, Czytelnictwo, s. 54.

${ }^{57}$ Scena nie odnotowana: Moisan, Matka Boska Pocieszenia; Moisan-Jabłońska, Obraz czyśćca w sztuce polskiego baroku, Warszawa 1995.
} 
kanonicy regularni przy ołtarzu i w stallach stanowili Kościół walczący poprzez m.in. modlitwy za dusze czyśćcowe ${ }^{58}$.

Uzupełnieniem tej sceny i jednocześnie ilustracją czterech rzeczy ostatecznych (śmierć, sąd, piekło, niebo) jest przedstawienie Sądu Ostatecznego z Maryją i św. Janem Chrzcicielem, apostołami oraz zmartwychwstaniem ciał i wizją ognia piekielnego, jakie znajduje się na łuku tęczowym od strony nawy. Ilustracyjny i dydaktyczny charakter tego malowidła jest przy tym oczywisty, choć podkreślić należy oryginalne miejsce jego prezentowania ${ }^{59}$.

W prezbiterium św. Augustyna ukazano również pośród Ewangelistów ${ }^{60}$ i cnót: Męstwa (Fortitudo), Roztropności (Prudentia), Sprawiedliwości (Iustitia), Umiarkowania (Temperantia), a także scen związanych z symboliką mszy świętej, gdzie z kolei znalazły się cnoty teologiczne (Caritas, Spes i Fides) ${ }^{61}$, ponad którymi znajduje się wyobrażenie Trójcy Świętej ${ }^{62}$. W wizerunku biskupa Hippony tym razem odwołano się do legendarnej sceny spotkania z Chrystusem jako chłopcem przelewającym wodę z morza. Wizja ta przekonała św. Augustyna o niemożności poznania tajemnicy Trójcy Świętej ${ }^{63}$. Przedstawienie to podkreśla jeden z najważniejszych tematów, jakie w swojej twórczości podejmował św. Augustyn. Inną dziedziną, którą się zajmował była aretologia. Stąd też przedstawienie personifikacji cnót teologicznych i kardynalnych. Ilustrują one przymioty świętego, które winien pielęgnować każdy chrześcijanin. Umieszczenie wyobrażeń cnót w przestrzeni prezbiterium, ponad stallami jest też szczególnym zobowiązaniem skierowanym do zakonników ${ }^{64}$.

Patronem kongregacji Bożego Ciała, którego święto kanonicy regularni laterańscy traktowali jako własne, był także Michał Archanioł. W każdym kościele wspólnoty krakowskiej dedykowano mu jeden z ołtarzy bocznych ${ }^{65}$. Tak było

${ }^{58}$ Moisan, Matka Boska Pocieszenia, s. 133-136, 138-139; Moisan-Jabłońska, Obraz czyśćca, s. $81,97-101,162-165$.

${ }^{59}$ Temat ten w świątyniach prezentowano w części zachodniej lub od strony wejścia do kościoła. Przy łukach tęczowych pojawiał się najczęściej Chrystus Ukrzyżowany rozumiany jako triumfator nad śmiercią.

${ }^{60}$ Św. Jan trzyma księgę z napisem: GOLOZ / ZAE //. Przy inskrypcjach słabo czytelnych zdecydowano się na podanie ich według wielkości zastosowanych liter i podziału na wersy.

${ }^{61}$ Przedstawieniom cnót towarzyszą zachowane fragmentarycznie inskrypcje. Na cokole personifikacji Nadziei znajduje się napis: CONSITIO EI //. Na płonącym sercu umieszczono napis: PARVEL $[\ldots] /[\ldots]$ / DIVUM [...] / OPUS [...] //. Poniżej serca znajduje się napis: GAUSAPE / PERVIUM E SOA / VERVIUM, / P[V]LVERIS / MASSA / SCEL [...] / CASSA //.

${ }^{62}$ Glob oplata, słabo dziś widoczna inskrypcja: [...] SINE L[...] POTENT [...] NE //. Przy czym początek napisu wydaje się być w odbiciu lustrzanym. Byłaby to zatem rozmowa pomiędzy Synem a Bogiem Ojcem.

${ }^{63}$ S. Aurelii Augustini Hipponensis Episcopi ... vita ... auctore ... Cornelio Lancilotto Erem. Augustiniano Exprouintiali S. Theologie Doctore. Antverpiae Ex Officina Plantiniana apud Viduam et Filios Io. Moreti 1616, s. 139 (o. E); Knipping, Iconography of the Counter Reformation, t. 1, s. 166-167.

${ }^{64}$ E. Zapolska, Cnoty teologalne i kardynalne, Kraków 2000, s. 15, 18, 33. Wyobrażenia cnót kardynalnych i teologicznych znalazły się także w dekoracji kaplicy św. Augustyna w kościele pw. śś. Piotra i Pawła na Antokolu w Wilnie. Czyż, Kościót pw. śś. Piotra i Pawła, s. 234.

${ }^{65}$ Oficjalnie Michała Archanioła ogłoszono patronem kongregacji krakowskiej w 1700 roku. Stało się to w wyniku osłabienia dyscypliny klasztornej oraz wojen, które wówczas pustoszyły 
i w Kraśniku, gdzie w prezbiterium po północnej stronie ustawiono snycerskie retabulum (konsekrowane 1762 roku $^{66}$ ) $\mathrm{z}$ wizerunkiem wodza wojsk niebiańskich (il. 3). Jego postać wieńczy także baldachim ambony wykonanej w 1775 roku, co należy uznać za rozwiązanie niezwykle oryginalne, bowiem w tym miejscu najczęściej umieszczano postać Chrystusa. W przypadku kazalnicy z kościoła kraśnickiego byłoby to o tyle logiczne, że na płaskorzeźbach kosza przedstawiono Przypowieść o siewcy, Dobrego Pasterza oraz Powrót syna marnotrawnego.

\section{Kult pasyjny i eucharystyczny}

W literaturze funkcjonuje opinia, że od początku XVII w. w Kraśniku działały dwa bractwa typowe dla pobożności i duszpasterstwa rozwijanego w kongregacji krakowskiej: Najświętszego Sakramentu i Pięciu Ran Pana Jezusa ${ }^{67}$. Jednak akta wizytacji z siedemnastego i osiemnastego stulecia odnotowują tylko bractwo Różańcowe ${ }^{68}$. Wydaje się, że w Kraśniku duszpasterstwu pasyjno-eucharystycznemu w przeciwieństwie do innych placówek kongregacji krakowskiej nie nadano sformalizowanych ram organizacyjnych. Duchowość ta była jednak rozwijana, czego świadectwem jest obraz Iudicium sanguinarium (Sąd Krwi) z drugiej połowy XVII w. ${ }^{69}$, który pełnił nie tylko funkcję ilustrującą niesprawiedliwy sąd nad Chrystusem, ale był pomocny w kontemplacji męki Zbawiciela oraz propagował pobożność pasyjną ${ }^{70}$.

Płótno przedstawia proces sądowy nad Chrystusem odbywający się w pretorium, siedzibie namiestnika prowincji Poncjusza Piłata. Ten i inne obrazy o tym tytule powstawały w okresie baroku jako ilustracja historycznego, jak wierzono, wydarzenia opartego o „odkrycie” w XVI w. wyroku ogłoszonego i spisanego przez Poncjusza Piłata ${ }^{71}$. Kraśnicka kompozycja wyróżnia się na tle innych przedstawień umieszczeniem obok siebie Piłata i Kajfasza, czyli przewodniczących rozprawy, jednakowo współwinnych skazania Chrystusa na śmierć ${ }^{72}$. Poniżej nich

Rzeczpospolitą. Od tego też momentu w kościele w Kraśniku obchodzono uroczyście jego wspomnienie. AKMK, AV Cap. t. 58 (1718), s. 47. Łatak, Kongregacja krakowska, s. 41-42, 76.

${ }^{66}$ Karpińska, Z kart historii miasta i kościoła, s. 19.

${ }^{67}$ Świadczy o tym nie tylko działalność bractwa Najświętszego Sakramentu przy krakowskim kościele, ale ilość kazań o tematyce eucharystycznej, które powstawały w środowisku kanoników regularnych laterańskich. Łatak, Kanonicy, s. 197-198, 275-278, 290-296; Łatak, Kongregacja krakowska, s. 28, 79.

${ }^{68}$ Wniosek o braku obu bractw został podany na podstawie ksiąg wizytacji przytoczonych w niniejszym artykule.

${ }^{69}$ Płótno o analogicznym temacie zrealizował w 1626 roku dla kościoła pw. Bożego Ciała w Krakowie Łukasz Porębski.

${ }^{70}$ Rupiewicz, Pierwowzory graficzne, s. 65-75; R. Rupiewicz, Sensacyjne odkrycia wyroków Pitata w XVI stuleciu. Jego źródła i oddziaływanie, w: Apud Patres. Prawo rzymskie w literaturze wczesnochrześcijańskiej, red. A. Dębiński, M. Wójcik, Lublin 2011, s. 133-157; R. Rupiewicz, Sędziowie Jezusa $w$ wizerunkach Concilium et sententia a perfidis Iudeis in Iesum Nazarenum Redemptorem Mundi w świetle przekazu ewangelicznego, w: Studia Anthropologica. Pogranicza historii sztuki i kultury, red. U. Mazurczak, Lublin 2013, s. 98-100, 106-107.

${ }^{71}$ Treść wyroku na obrazie z Kraśnika została umieszczona w kartuszu w dolnej części kompozycji.

${ }^{72}$ Taki ikonograficzny motyw pojawił się w 2. poł. XVII w., a prawzorem dla niego była grafi- 
znajduje się pisarz i lektor oraz sam skazaniec. W procesie bierze udział także dziewiętnastu Żydów, członków Wysokiej Rady. Każdy z nich trzyma tabliczkę zawierającą imię oraz wypowiedź oskarżającą lub broniącą (m.in. Józef z Arymatei, Achias, Subatch, Nikodem) Zbawiciela. W górnej części na skrajach kompozycji ukazano konsekwencje skazującego wyroku, czyli Pojmanie i Ukrzyżowanie ${ }^{73}$.

Z kultem pasyjnym wiąże się kult eucharystycznego ciała Chrystusa, który w środowisku kanoników regularnych był ściśle połączony z historią i wezwaniem świątyni krakowskiej. Stąd też zakonnicy ogromną wagę przywiązywali nie tylko do samej mszy świętej, ale i oprawy, która winna jej towarzyszyć. W latach 20. XVII w. środowisku kanoników kongregacji krakowskiej uznano, że najlepszy dla nowej, zreformowanej po soborze trydenckim liturgii będzie typ ołtarza architektonicznego opartego o schemat trójprzelotowego łuku triumfalnego. Forma taka idealnie wpisywała się w potrzebę kreowania bogatej oprawy mszy świętej, która miała być przedsmakiem liturgii niebiańskiej ${ }^{74}$.

W takim kształcie ok. 1630 roku wykonał ołtarz główny do kościoła w Kraśniku bliżej nieznany snycerz małopolski Jakub Piszczarek ${ }^{75}$. W architektonicznej strukturze znalazły się nisze, w których ustawiono figury ojców Kościoła (Grzegorza Wielkiego i Augustyna, Hieronima i Ambrożego), których kanonicy regularni identyfikowali z własnym zgromadzeniem ${ }^{76}$. W ołtarzu głównym umieszczono także wyobrażenia Ewangelistów oraz patronów Rzeczpospolitej (Wojciecha i Stanisława, Zygmunta i Floriana), których kult kanonicy regularni obowiązkowo propagowali w swoich świątyniach, a szczególnie w placówkach położonych tak jak Kraśnik w diecezji krakowskiej ${ }^{77}$. W partii cokołowej ołtarza umiesz-

ka z Universitätsbibliothek Erlagen-Nürnberg (inw. AI 38, dawna sygn. Kasten IV.24). Informacje zawdzięczam Romanie Rupiewicz, która na temat ikonografii Iudicium sanguinarium przygotowuje obszerne opracowanie.

${ }^{73}$ Rupiewicz, Pierwowzory graficzne, s. 58-61; Rupiewicz, Sędziowie Jezusa, s. 86-97.

${ }^{74}$ Ołtarze wykonywane dla kanoników regularnych laterańskich (Sucha Beskidzka, po 1624 roku; Kraków, 1634-1637; ołtarz-konfesja bł. St. Kazimierczyka, przed 1632 roku) oparto o schemat Arco dei Gavi z Werony (145). Ten trójprzelotowy, dzielony kolumnami korynckimi z trójkątnym naczółkiem w partii środkowej, łuk spopularyzował wzornik Sebastiana Serlia (księga III). Pasierb, Problematyka sztuki, s. 1463-1464, 1471-1476; Krasnowolski, Zapomniane sankuarium, s. 136; M. Wardzyński, Ze studiów nad snycerstwem krakowskim i małopolskim około roku 1630, w: Studia nad sztuka renesansu i baroku, red. J. Lileyko, I. Rolska-Boruch, Lublin 2004, t. 5, s. 64-68.

${ }^{75}$ Zapewne w tym samym czasie i w tym samym warsztacie powstał ołtarz bractwa Różańcowego. Warto podkreślić, że oba ołtarze są jednymi z najważniejszych realizacji snycerskich 1 poł. XVII w. na Lubelszczyźnie. Samek, Polskie rzemiosto, s. 153-154. W aktach wizytacji z 1682 roku ołtarz i tabernakulum opisano jako, ,in totaliter in aurato”. AKMK, AV, t. 12, s. 92.

${ }^{76}$ Św. Ambroży przyjaźnił się z matką św. Augustyna. Przyczynił się do nawrócenia przyszłego biskupa Hippony, a także go ochrzcił. Grzegorz Wielki to pierwszy zakonnik benedyktyn na tronie Piotrowym. Kanonicy regularni laterańscy uważali go za członka swego zgromadzenia. R. Fischer-Wollpert, Leksykon papieży, Kraków 1996, s. 37-38; Łatak, Kanonicy regularni, s. 18, 197

${ }^{77}$ Szczególnie bliski był kanonikom regularnym kult św. Floriana i św. Stanisława, którzy ukazali się podczas jednej z wizji św. Kazimierczykowi, zakonnikowi z klasztoru Bożego Ciała w Krakowie. Żywy wzór Apostolskiea doskonałości, B. Stanisław Kazimierczyk, w sławnej Akademiej Krakowskiej Profesor, i S. Teologiej Bakatarz, Zakonu Canonicor. Regular. S. Salvatoris Lateran.The- 
czono natomiast płaskorzeźby przedstawiające Mojżesza i Aarona, zapowiadających kapłaństwo i ofiarę Chrystusa (il. 4). Ołtarz ozdobiono wyobrażeniami aniołów z koszami wypełnionymi owocami oraz wiciami akantowymi i winnych latorośli, co w związku z symboliką pasyjną i eucharystyczną ewokuje niebo, obiecaną krainę wszystkich wierzących, gdzie wiecznie trwa niebiańska uczta ${ }^{78}$. Wskazuje na nią figura Zmartwychwstałego w zwieńczeniu ołtarza, któremu towarzyszą aniołowie z banderolą „Truimphatori Immortali”. Chrystus trzyma krzyż - znak swego zwycięstwa. Obok umieszczono kielich podkreślając raz jeszcze pasyjno-eucharystyczną symbolikę. Kielich z hostią - insygnium zwycięstwa znajduje się także w tympanonie na osi pierwszej kondygnacji ${ }^{79}$.

Dopełnieniem wątku eucharystycznego w ołtarzu głównym są dwa obrazy namalowane ponad bramkami cokołu. Przedstawiają one kluczowe etapy mszy świętej: podniesienie (il. 5) i komunię (il. 6). I w Podniesieniu i w Komunii ponad hostią jaśnieje maleńkie Dzieciątko Jezus, co jest wskazaniem na prawdziwość przeistoczenia chleba w ciało Chrystusa podczas mszy świętej. Ujęcie takie dosłownie przypomina dogmat o realnej i substancjalnej obecności Zbawiciela pod postacią wina i chleba, a więc wyraźnie podkreśla to co kwestionowali protestanci. Nie można wykluczyć, że wbrew dotychczasowej praktyce duszpasterskiej, ale zgodnie z zaleceniami Soboru Trydenckiego była to zachęta, aby często przyjmować komunię świętą. Co ciekawe pomysł częstego komunikowania jako pierwsi wysunęli teolodzy związani z czeskim ruchem devotio moderna, który był bardzo silny także w środowisku kanoników regularnych skupionych wokół kościoła pw. Bożego Ciała ${ }^{80}$. Nie przypadkowo w świątyni w Kraśniku w jednym z ołtarzy bocznych znalazł się też obraz komunii św. Marii Egipcjanki (2 poł. XVIII w.), który także należy interpretować w kontekście nauki o Eucharystii oraz ilustracyjnej zachęty skierowanej do wiernych ${ }^{81}$.

olog i Przeor ... Przez X. Aquilina Michała Gorczyńskiego Prawa Duchownego i Pisma S. Doktora i Profesora, S. Stolice Apostolskiei Pisarza, tegoż Zakonu i u Bożego Ciała na Kazimierzu Kanonika światu wystawiony. Roku 1702 w Krakowie w drukarni Akademickiej, s. 26, 32 (E XVII, 244-245); Żywot, sprawy y cudowne Boskie wstawienie pobożnego Kaptana B. Stanisława Kazimirczyka, s. 33, 36; Joannis de Nigra Valle, s. 104-109 Łatak, Kanonicy, s. 199-200, 282-283; Łatak, Kongregacja krakowska, s. 28; A. Jankowski, Myśl augustiańska w programie ikonograficznym barokowych malowidet ściennych kościoła drewnianego w Gasawie, „Biuletyn Historii Sztuki”, 3/4 (2004) t. 66, s. 278-279. Poza tym warto pamiętać, że kościół w Kraśniku na początku XVI w. miał poczwórne wezwanie prócz maryjnego i kanonickiego także św. Pawła oraz św. Stanisława. Korolec, Biblioteki Lubelszczyzny, s. 106; Karpińska, Z kart historii miasta i kościoła, s. 15.

${ }^{78}$ J. J. Kopeć, Interpretacja malowidet pasyjnych na szafach brackich z kaplicy św. Anny $w$ krakowskim kościele Bożego Ciała, w: Studia, s. 158-160; S. Kobielus, Floralium christianum. Symbolika roślin - chrześcijańska starożytność i średniowiecze, Tyniec 2006, s. 24, 220-224.

${ }^{79}$ Gospodarz Nieba i Ziemie, Jezus Chrystus, Syn Bozy, Bóg wcielony, Zbawiciel i Naprawca Świata w przednie Tajemnic i dziet swoich uroczystości, Pobożnemu Auditorowi na kazaniach wystawiony, od X. Jacka Liberiusza S. T. Doktora Proboszcza kośćioła Bożego Ciała na Kazmierzu przy Krakowie. W Kazimierzu przy Krakowie w Drukarni Balcera Smieszkowicza Typ. R. P. 1665, s. 432, 442 (E XXI, 260); Kopeć, Interpretacja malowidet pasyjnych, s. 143-145, 149-152.

${ }^{80} \mathrm{M}$. Janocha, Missa in arte polona. Ikonografia mszy świętej $w$ średniowiecznej i nowożytnej sztuce polskiej, Warszawa 1998, s. 41, 48-49, 51-52, 56-57.

${ }_{81}$ Trudno omawiane sceny połączyć z konkretnymi wydarzeniami historycznymi, choć nie można wykluczyć, że mają one właśnie taki charakter. Obie rozgrywają się w dwóch różnych świą- 
Do kultu eucharystycznego ciała Chrystusa odwołują się także sceny namalowane w osiemnastym stuleciu w prezbiterium kościoła w Kraśniku. Jedna z nich przedstawia Ofiarę Melchizedeka ${ }^{82}$, która była zapowiedzią ofiary Chrystusa. Ten z kolei temat ukazano poprzez Zbawiciela, który dosłownie sam siebie składa na ołtarzu w asyście dwóch diakonów ${ }^{83}$. Obok znajduje się alegoryczna scena przepędzania heretyków z Kościoła. Jest to kompozycja dwustrefowa: w górnej znajduje się Chrystus przedstawiony w konwencji Dobrego pasterza w otoczeniu muzykujących aniołów, poniżej z obłoków wystają dwie trąby, których dźwięk przepędza lisy. Przy obłokach znajdują się dwie banderole z napisami: HONORA [DO]MIN[UM] [...]ILL [...]RT [...]IOM [...]NONA // oraz ERRAVI SICUT OVIS [QUAE] PERIIT // (Ps 118, 176).

Symbolikę tych kompozycji można oprzeć na rozważaniach św. Augustyna o Psalmie 33: „Żydzi dawniej znali ofiarę ze zwierząt ofiarnych według obrządku Aarona. Ofiara miała tajemnicze znaczenie. Nie było jeszcze ofiary Ciała i Krwi Pańskiej, jaką znają wierzący [...]. Napisano bowiem «Przysiągł Pan i nie będzie żałował: Ty jesteś kapłanem na wieki według obrządku Melchizedeka». O kim powiedziano [...]? O Panu naszym Jezusie Chrystusie. [...] Jak wielki był Melchizedek, który błogosławił Abrahama. Przyniósł chleb i wino. [...] Zniesiona zatem została ofiara Aarona, a zaczęła się ofiara według obrządku Melchizedeka. [...] Pan nasz Jezus Chrystus. Chciał, aby zbawienie nasze dokonało się w krwi i ciele Jego" $"$.

Jako że lisy wyrządzały wiele szkód w winnicach już w starożytności biblijnej nie tylko stawiano strażnice czy choćby szałasy, ale odstraszano je krzykiem lub trąbieniem. Winnica to od wczesnego chrześcijaństwa symbol Kościoła, natomiast lisy interpretowano jako znak szatana ${ }^{85}$. Św. Augustyn w komentarzu do Psalmu 80 poprzez skojarzenie z fragmentem Pieśni nad Pieśniami „Schwytajcie nam lisy, małe lisy pustoszące winnice, kryjące się w norach krętych” (Pnp 2, 15),

tyniach i są aktualizowane. Podniesienie (il. 5) usytuowano we wnętrzu gotyckim, przed ołtarzem z wizerunkiem Ukrzyżowania i dalekim widokiem na pałac, w którego oknie widać władce noszącego na piersiach order Złotego Runa. Komunię (il. 6) przedstawiono we wnętrzu o cechach nowożytnych, przed ołtarzem z wizerunkiem Zmartwychwstałego Chrystusa. Osobą przyjmującą komunię świętą jest król w liturgicznej kapie. Obok niego znajdują się dostojnicy, zapewne jego krewni ubrani w królewskie płaszcze z wyraźnie zaznaczonym łańcuchem od orderu Złotego Runa. Scenie przygląda się brodaty książę, ubodzy i kalecy a także żołnierze. Według prof. Krystyny Moisan-Jabłońskiej sceny te mogą ilustrować konkretne cuda eucharystyczne.

${ }^{82}$ Scenie towarzyszą anielscy akolici, trzymający m.in. kadzielnicę i trybularz. Ponad sceną znajduje się gołębica Ducha Świętego wyłaniająca się z obłoków, gdzie namalowano także banderolę z napisem „Melchizedech”.

${ }^{83}$ Temat ten kontynuuje przedstawienie Alegorii Wiary, której słabo czytelne fragmenty znajdują się w dawnej kaplicy Ukrzyżowania Chrystusa. Siedemnastowieczne sceny związane z eucharystią znajdują się także ponad stallami w prezbiterium kościoła pw. Bożego Ciała. Umieszczono je także na sklepieniu prezbiterium świątyni antokolskiej. Czyż, Kościót pw. śś. Piotra i Pawła, s. 241.

${ }^{84}$ Św. Augustyn, Objaśnienia do Psalmów, tłum. i wstęp J. Sulowski, oprac. E. Stanula, Warszawa 1986, cz. 1, s. 326. Zob. także Kobielus, Concordia Novi, s. 49-50.

${ }^{85}$ S. Kobielus, Krzyż Chrystusa. Od znaku i figury do symbolu i metafory, Warszawa 2000, s. 227-230; S. Kobielus, Bestriarium chrześsijańskie. Zwierzęta w symbolice i interpretacji. Starożytność i średniowiecze, Warszawa 2002, s. 193-194. 
pisał: „lisy podstępne, w szczególności oznaczają heretyków” ${ }^{86}$. Pisarze wczesnochrześcijańscy rozumieli krzyż jako strażnicę, a Chrystusa jako strażnika w winnicy Kościoła, strzegącego ją przed wszelkim złem. W ten sposób symbolika ta łączyła się także z pasyjno-eucharystycznymi metaforami ${ }^{87}$.

\section{Wątek związany z duchowością maryjną}

W ołtarzu głównym kościoła w Kraśniku nie tylko zaakcentowano symbolikę eucharystyczną, ale także osobę Maryi, której została dedykowana świątynia. W centralnym polu ołtarza pierwotnie znajdowała się Koronacja Najświętszej Maryi Panny pędzla Jana Kasińskiego (obecnie wizerunek Matki Boskiej Śnieżnej z ok. 1620 roku, na zasuwie Wniebowzięcie z lat 1900-1904) $)^{88}$, nadwornego malarza Tomasza Zamoyskiego ${ }^{89}$. Temat obrazu jaki został namalowany w 1631 roku, inny niż wezwanie kościoła, z rozwagą wybrał ówczesny prepozyt kraśnicki Jan Chrzciciel Malanowski powołując się na tradycję miejsca i oczekiwania wiernych ${ }^{90}$.

Górną część kompozycji obrazu stanowi właściwa koronacja, a w dolnej znajdują się święci adorujący scenę. Wśród nich rozpoznajemy patronów Rzeczpospolitej (św. Stanisław, św. Kazimierz, św. Wojciech), przedstawiciela apostołów św. Tomasza, który był patronem II ordynata ${ }^{91}$ oraz zakonów: jezuitów (św. Stanisław Kostka, św. Ignacy?), dominikanów (św. Dominik, św. Katarzyna ze Sieny ${ }^{92}$ ), św. Barbarę ${ }^{93}$, a także związanego z odnową posoborową św. Karola Boromeusza $^{94}$. Na obrazie przedstawiono także św. Jana Chrzciciela patrona bazyliki laterańskiej, z którą związani są kanonicy regularni ${ }^{95}$. Święci spoza ścisłego grona kanoników regularnych to odwołanie do kojonego toposu historii zgromadzenia, z którego ,jakoby z raju rozkoszy cztery rzeki to jest cztery Mendicantium, abo żebrzących $\mathrm{z}$ dobrowolnego ubóstwa zakonny początek wzięły. Zakon kaznodziejski ś. Dominika, który w zakonie kanoników laterańskich pierwej żywot prowadząc potym zakon kaznodziejski w Kościele powszechnym [...] założył. Zakon Minorum ś. Franciszka, Eremitów i Karmelitów, którzy wszyscy przykładem

\footnotetext{
${ }^{86}$ Św. Augustyn, Objaśnienia do Psalmów, cz. 4, s. 36.

${ }^{87}$ Kobielus, Krzyż Chrystusa, s. 230-232.

${ }^{88}$ Obraz został przewieszony na ścianę kościoła, a na jego miejsce wprawiono płótno namalowane przez Salon Artystyczny w Warszawie. Odnowiony ołtarz konsekrowano w 1904 roku. Kowalczyk, Koronacja Najświętszej Maryi Panny, s. 142.

${ }^{89}$ Artysta wyszedł najpewniej z pracowni Tomasza Dolabelli. Dla Tomasza Zamoyskiego pracował od 1626 roku. Tamże, s. 142.

${ }^{90}$ Tamże, s. 140-141, 145.

${ }^{91}$ Tamże, s. 144-145. Nie przypadkowo przy wizerunku św. Tomasza występuje herb Jelita.

${ }^{92}$ Tutaj także w roli patronki ordynatki Katarzyny z Ostrogskich. Tamże, s. 144.

${ }^{93}$ Patronka matki I ordynata.

${ }^{94}$ Święty czczony w kościele pw. Bożego Ciała, gdzie dedykowano mu jeden z ołtarzy bocznych z 1 . ćw. XVII w.

${ }^{95}$ Był on patronem Jana Zamoyskiego, a także najstarszego syna Tomasza zwanego później Sobiepanem.
} 
i przepowiadaniem swoim Kościoła Chrystusowego okrąg, jako najpiękniejsze rzeki polewają"96.

Najliczniej są jednak reprezentowani kanonicy regularni laterańscy, skupieni wokół swego prawodawcy, a wśród nich na pierwszym planie ukazano zmarłego w opinii świętości Stanisława Kazimierczyka ${ }^{97}$. Św. Augustyna na omawianym obrazie przedstawiono w stroju zakonnym, w liturgicznej kapie świadczącej o jego biskupiej posłudze, a także z modelem kościoła w dłoniach. U jego stóp znajduje się księga $\mathrm{z}$ inicjałem $\mathrm{C}$, co jest aluzją do najsłynniejszego dzieła „Wyznania” („Confessiones”). Świątynia w lewej dłoni świętego przybrała postać gotyckiej budowli otoczonej murem z dzwonnicą, co przypomina kościół w Kraśniku sprzed nowożytnych przemian ${ }^{98}$. Św. Augustyn został więc ukazany nie tylko jako patron kanoników regularnych laterańskich, ale szczególny opiekun wspólnoty kraśnickiej, którą oddaje w opiekę Maryi i Trójcy Świętej. Jednocześnie jest to dar, jaki zakonnicy wraz z wiernymi skupionymi wokół kościoła składają sami z siebie ślubując wierność Bogu i Maryi ${ }^{99}$.

Przy każdej świątyni kongregacji krakowskiej powstawało także bractwo rozwijające duchowość maryjną. W Kraśniku od 1609 roku funkcjonowało bractwo Różańcowe, które propagując stosunkowo nową formę nabożeństwa określanego jako „skrócona Ewangelia”, łączyło modlitwę z kontemplacją prawd wiary, idealnie wpisując się w zalecenia potrydenckiego Kościoła ${ }^{100}$.

Na potrzeby bractwa od południowej strony prezbiterium dobudowano kaplicę, którą ok. połowy XVIII w. przebudowano i ozdobiono freskami ${ }^{101}$. Podczas późnobarokowej modernizacji pozostawiano jednak ołtarz, który powstał zapewne w tym samym czasie i w tym samym warsztacie co ołtarz główny ${ }^{102}$. Pierwotnie w ołtarzu kaplicy brackiej prezentowano kopię obrazu Matki Boskiej Śnieżnej

${ }^{96}$ Krótka nauka, k. 25.

${ }^{97}$ Według Jerzego Kowalczyka jest to portret prepozyta Jana Chrzciciela Malanowskiego (Kowalczyk, Koronacja Najświętszej Maryi Panny, s. 144). Postać zakonnika nie przypomina jednak postaci utrwalonej na portrecie (2 poł. XVII w.), jaki znajduje się na plebani. Wpisuje się natomiast w ikonografię wizerunków św. Stanisława Kazimierczyka z siedemnastego stulecia, które w znacznej ilości nadal przechowywane są w kościele i klasztorze Bożego Ciała w Krakowie.

${ }^{98}$ Kowalczyk, Koronacja Najświętszej Maryi Panny, s. 144.

${ }^{99}$ Wątek maryjny powraca w jednym z ołtarzy bocznych, gdzie ukazano obraz św. Anny Samotrzeć, a powyżej w zwieńczeniu św. Elżbietę ze św. Janem Chrzcicielem, co jest z kolei podkreśleniem osoby patrona bazyliki na rzymskim Lateranie. Katalog zabytków (s. 17) podaje, że jest to Maryja ze św. Janem Chrzcicielem.

${ }^{100}$ K. S. Moisan, Matka Boska Różańcowa, w: Maryja orędowniczka, s. 44, 48. Katalog zabytków, s. 11.

${ }^{101}$ Karpińska, Z kart historii miasta i kościoła, s. 19. Malowidła w tamburze przedstawiają ojców Kościoła (św. Grzegorz Wielki, św. Hieronim, św. Ambroży) ze św. Augustynem na czele, postacie aniołów z banderolami, a także wizerunek Matki Boskiej Śnieżnej unoszony przez anioły. W kopule znajdują się wizerunki świętych: Agnieszki, Apolonii, Katarzyny Aleksandryjskiej, Barbary, Dominika, Matki Boskiej, Antoniego i Katarzyny Sieneńskiej, popularnych w kręgu kanoników regularnych laterańskich. Czyż, Kościót pw. śś. Piotra i Pawła, s. 239.

${ }^{102}$ M. Wardzyński, Ze studiów nad snycerstwem, s. 68 . W 1682 roku zapisano „Veste argentea et tabellis Virginis adornata". AKMK, AV t. 12, s. 92. 
(obecnie Matki Boskiej Nieustającej Pomocy), który ofiarował świątyni Tomasz Zamoyski ${ }^{103}$.

Gest II ordynata nie był przypadkowy. Zgodnie z tradycją obraz Matki Boskiej Śnieżnej namalowany przez św. Łukasza był najcenniejszą relikwią maryjną Wiecznego Miasta, przechowywaną w bazylice S. Maria Maggiore, najważniejszym i najstarszym europejskim sanktuarium poświęconym Bogurodzicy. Od XVI w. wizerunek ten, podobnie jak inne obrazy religijne był przedmiotem sporu pomiędzy katolikami a luteranami i przede wszystkim kalwinistami także na terenie Lubelszczyzny, o czym pisał wspomniany wyżej ks. Jan Augustyn Biesiekierski ${ }^{104}$. Wizerunek Matki Boskiej Śnieżnej w kontekście podkreślania trwałości tradycji Kościoła rzymskiego stał się niezwykle ważny w okresie kontrreformacji, szczególnie w kontekście połączenia obrazu z modlitwą różańcową oraz ze zwycięstwem pod Lepanto w 1571 roku $^{105}$.

Kopie wizerunku Salus Populi Romani wysłano do najodleglejszych zakątków świata chrześcijańskiego. W Rzeczpospolitej kult Matki Boskiej Śnieżnej był najsilniejszy w pierwszej połowie XVII w. łącząc się i z kontrreformacją i z zagrożeniem tureckim, które zgodnie z ideą antemurale christianitatis skonkretyzowało się podczas zwycięskiej obrony Chocimia w 1621 roku. Znano go przy tym przede wszystkim w diecezji krakowskiej, gdzie cześć Maryi w obrazie Salus Populi Romani była propagowana głównie przez zakonników i bractwa różańco$\mathrm{we}^{106}$.

${ }^{103}$ Tomasz Zamoyski charakteryzujący się głęboką pobożnością maryjną ofiarował wizerunek, zapewne w momencie erygowania bractwa. Inną kopię obrazu podarował do kościoła w Janowie. Jego krewny, a zarazem opat w Czerwińsku Jan Zamojski zlecił w 1612 roku namalowanie obrazu Matki Boskiej Śnieżnej do świątyni mazowieckiej. Podkreślić także należy, że wizerunek Salus Populi Romani był w XVII w. niezwykle popularny na Lubelszczyźnie, co wiąże się z aktywnością kalwinistów i arian na tym terenie. Na zasuwie ołtarza brackiego w Kraśniku znajdował się obraz św. Walentego, który obecnie jest przechowywany na plebanii. Płótno powstało w 2 poł. XVII w. Kult patrona chorych rozwinął się w kontekście szpitala prowadzonego w Kraśniku przez kanoników regularnych laterańskich. Kowalczyk, Koronacja Najświętszej Maryi Panny, s. 139-140; Karpińska, Z kart historii miasta i kościoła, s. 18. Według karty inwentaryzacyjnej z Narodowego Instytutu Dziedzictwa obraz św. Walentego został zakupiony przez parafię ok. 1900 roku. H. Orzechowska, karta nr WX 260001899 (LBL 000008266). Zob. także Łatak, Kanonicy, s. 71.

${ }^{104}$ Krótka nauka, k. 2v-3, 5 i nn. Zob. J. Tazbir, Różnowiercy a kult maryjny, w: Prace wybrane, t. 4 Studia nad kultura staropolska, Kraków 2001, s. 6-28.

${ }^{105}$ Obraz (typ Hodegetrii) przeniesiono w 1613 r. do kaplicy ufundowanej przez Pawła V. Nastawie nadano tradycyjną formułę edikuli, a także ramę w formie pełnoplastycznych aniołów. Podobnie jak nastawy w Cappella Gregoriana i w Chiesa Nuova ołtarz z Santa Maria Maggiore przyczynił się do wykształcenia specyficznego prezentowania dawnych wizerunków w nastawach architektonicznych o schemacie edikuli z rzeźbiarskim obramieniem. Był to efekt dostosowania małych wizerunków do monumentalnych nastaw ołtarzowych. M. Kornecki, Matka Boska Polska. Adaptacja i rozpowszechnienie typu ikonograficznego obrazu Matki Boskiej Śnieżnej od XVI do XVIII wieku, w: Dzieje Lubelszczyzny, t. 6 cz. 3 Kultura artystyczna, red. T. Chrzanowski, Lublin 1992, s. 365. G. Jurkowlaniec, Epoka nowożytna wobec średniowiecza. Pamiatki przeszłości, cudowne wizerunki, dzieła sztuki, Wrocław 2008, s. 95-100, 102-103, 295-298.

${ }^{106}$ Obraz ten znany był także w innych placówkach kanoników nie wchodzących w skład kongregacji krakowskiej, w Mstowie i we wspomnianym Czerwińsku. Kornecki, Matka Boska Polska, 365-366, 370-371, 379, 389. Zob. także Tazbir, Różnowiercy, s. 28, 31-33. 
W ołtarzu brackim znajdują się także liczne rzeźbione i malowane wizerunki, dopełniające treści związane $\mathrm{z}$ Maryją, jako królową świętych ${ }^{107}$. Wśród nich są figury patronów rzymskiej bazyliki na Lateranie (św. Jan Ewangelista i św. Jan Chrzciciel ${ }^{108}$ ), patronów Rzeczpospolitej (św. Stanisław i św. Wojciech, św. Jadwiga i św. Kazimierz), a także święci związani z modlitwą różańcową (św. Katarzyna ze Sieny i św. Dominik $\left.{ }^{109}\right)$. W predelli znalazł się wspomniany już obraz Matki Boskiej z Dzieciątkiem i św. Augustynem, którym towarzyszą św. Apolonia i św. Agnieszka. Po bokach umieszczono malarskie wizerunki świętych biskupów Marcina i Mikołaja, których kanonicy uważali za członków swego zakonu. W uszakach przedstawiono św. Katarzynę ze Sieny oraz św. Teresę z Avila ${ }^{110}$.

Cześć Maryi oddawana za pośrednictwem kopii wizerunku Matki Boskiej Śnieżnej, którego kult był intensywnie propagowany przez Piusa V, wiąże się także z trzema płótnami, jakie dla bractwa Różańcowego namalował Tomasz Dolabella. Choć upamiętniają one zwycięską bitwę pod Lepanto, jaka rozegrała się dzięki wstawiennictwu Bogurodzicy czczonej w obrazie z Santa Maria Maggiore, są aluzją do współczesnych wydarzeńn ${ }^{111}$.

Pierwszy z obrazów ukazuje wizję gniewu Bożego (Iudicium mysticum Chri$s t i)^{112}$. U podstaw tego tematu leży przeświadczenie, że Bóg nie mogąc znieść

${ }^{107}$ W ołtarzu znalazło się także malarskie przedstawienie Koronacji Najświętszej Maryi Panny oraz wizerunek św. Dominika. Łączenie w sztuce wizerunku Matki Boskiej Śnieżnej z postaciami patronów Polski występuje na siedemnastowiecznych obrazach z Kotłowa, Śremu, Pinczowa oraz Warki. Kornecki, Matka Boska Polska, s. 394-395. Wizytator kościoła w 1748 roku zanotował: „In capella B. M. V. picturae reperiuntur eximiae, prout et in aliis ecclesiae locis, et altaribus”. AKMK, AV t. 45, k. 91v. Obraz Maryi w ołtarzu brackim był wówczas nakryty srebrną sukienką, zdobiły go także dwie korony i dwa berła. AKMK, AV t. 45, k. 92.

${ }^{108}$ Figury najpewniej pierwotnie stały w tej samej, drugiej kondygnacji, obecnie św. Jan Chrzciciel znajduje się w dolnej niszy.

${ }^{109}$ Figura św. Dominika znajdowała się pierwotnie w dolnej niszy, na tym samym poziomie co wyobrażenie św. Katarzyny ze Sieny.

${ }^{110}$ W Katalogu zabytków (s. 17) błędnie zidentyfikowano większość postaci występujących w ołtarzu.

${ }^{111}$ Bitwa pod Lepanto (Nefpaktos, zachodnia Grecja) rozegrała się podczas naporu Turków na Europę, kiedy to w maju 1571 roku w bazylice św. Piotra w Rzymie uroczyście proklamowano utworzenie ligi z udziałem Hiszpanii, Wenecji i wojsk papieskich wymierzonej przeciw muzułmanom. Inicjatorem działań był Pius V, który w intencji zwycięstwa zarządził uroczysty jubileusz i publiczne modlitwy, a sam podjął surową pokutę. 7 X ulicami Rzymu przeszła procesja bractwa różańcowego z wizerunkiem z Santa Maria Maggiore, podczas której papież doznał wizji triumfu wojsk chrześcijańskich. Pod wpływem widzenia odprawił w bazylice św. Piotra mszę dziękczynną w obecności zdziwionych wiernych. Kiedy wiadomość o zwycięstwie dotarła do Rzymu, okazało się że stało się to dokładnie w momencie, kiedy ulice obchodziła procesja różańcowa. W tym samym co w Rzymie czasie procesje zarządzono w Wenecji, której panowaniu w basenie Morza Śródziemnego zagrażała nawałnica muzułmańska. Dla uczczenia wiktorii, która ocaliła Europę przez naporem muzułmańskim Pius V ustanowił święto Matki Boskiej Zwycięskiej, które następnie Grzegorz XII polecił obchodzić w pierwszą niedzielę października jako święto różańcowe we wszystkich kościołach posiadających ołtarz różańcowy, nadając uczestnikom liturgii odpust zupełny. Kornecki, Matka Boska Polska, s. 365; Janocha, Missa in arte polona, s. 148; Jurkowlaniec, Epoka nowożytna, s. 295-296. Święto Matki Boskiej Różańcowej było uroczyście obchodzone także w kościele w Kraśniku. AKMK, AV t. 12, s. 92; AV t. 45, s. 91v; AV Cap. t. 66, s. 48.

112 Tytuł jest częścią inskrypcji, która znajduje się na obrazie: IUDICIUM MYSTICUM CHRISTI DOMINI SERVATORIS / NOSTRI CLEMENTISSIMI, CUM INGRATO MUNDO IA[M] 
grzechu pychy, łakomstwa i nieczystości zsyła karę w postaci plag: głodu, moru i wojny. Wybawicielką jest jednak Maryja, która błagając Syna o litość wskazuje prawych zakonników, dzięki którym na świecie będą pielęgnowane trzy cnoty: posłuszeństwo, ubóstwo i czystość. Formuła, którą w dobie baroku przedstawiano dość często także w środowisku kanoników regularnych laterańskich, w Kraśniku została znacznie rozbudowana ${ }^{113}$.

Scenę podzielono na trzy części. W górnej znajduje się Chrystus ciskający strzały w ludzkość przedstawioną w dolnej partii obrazu. Obok Zbawiciela znajduje się Maryja oraz apostołowie w tym Piotr i Jan, a za nimi m.in. Mojżesz i Aaron. Poniżej gołębicy Ducha Świętego ukazano proroków, wśród których można rozpoznać Dawida. Po stronie Boga Ojca znajdują się apostołowie, w tym św. Paweł. Środkowa kondygnacja nieba to ewangeliści oraz ojcowie Kościoła: Augustyn, Hieronim, Grzegorz Wielki i Ambroży. Obie te grupy według Władysława Tomkiewicza dostarczają argumentów przeciw ludzkości ${ }^{114}$. Między nimi na dalszym planie widać grupę świętych kobiet, którym przewodzą czczone w środowisku kanoników regularnych: św. Agnieszka, św. Katarzyna i św. Barba$\mathrm{ra}^{115}$ oraz mężczyzn, gdzie przedstawiono m.in. św. Maurycego ${ }^{116}$ i św. Ignacego Loyolę. W dolnej części obrazu znajdują się personifikacje pychy, nieczystości i łakomstwa, które niosą sztandary przewodnicząc procesji grzeszników. Obok nich wyeksponowano zakonników: św. Franciszka i św. Dominika oraz św. Tomasza z Canterbury ${ }^{117}$ i św. Leona Wielkiego, a także św. Karola Boromeusza. Są to najwierniejsi z obrońców grzesznych ludzi, którzy współdziałają z Maryją ${ }^{118}$.

Kolejny obraz to Procesja różańcowa, na którym przedstawiono symultanicznie bitwę morską pod Lepanto i przebłagalną procesję różańcową w Wenecji ${ }^{119}$.

/ IAM PERITURE, SED PRECIBUS ET INTERCESSION[IS] / B. V. MARIAE IUSTUS DOMINI FUROR ADHUC PLACATU[S] / EST, PROUT MULTIS DEVOTIS HUIUS SS. MARIAE SE[R] / VIS EST REVELATUM //. Inskrypcja według W. Tomkiewicz, Obrazy Dolabelli w Kraśniku, w: tenże, Pędzlem rozmaitym. Malarstwo okresu Wazów w Polsce, Warszawa 1970, s. 205.

${ }^{113}$ Sceny związane z gniewem Bożym zrealizowano w wersji stiukowej w kościele pw. śś. Piotra i Pawła na Antokolu w Wilnie. Ponadto w świątyni tej umieszczono wizerunek Matki Boskiej Łaskawej, która łamie strzały gniewu Bożego. Czyż, Kościół pw. śś. Piotra i Pawła, s. 242.

${ }^{114}$ Tomkiewicz, Obrazy, s. 206.

${ }^{115}$ Nie można wykluczyć, że dobrano je także według klucza patronek kobiet związanych z domem Zamoyskich. Tamże, s. 206; Czyż, Kościót pw. śś. Piotra i Pawła, s. 239-240.

${ }^{116} \mathrm{~W}$ Agaunum (Saint-Maurice), w miejscu męczeństwa dowódcy wojsk tebańskich św. Maurycego wzniesiono opactwo, które w 1128 roku przeszło w ręce kanoników regularnych. Święty występuje także wśród stiukowych figur kościoła pw. śś. Piotra i Pawła na Antokolu w Wilnie. H. Fros, F. Sowa, Księga imion świętych, Kraków 2000, t. 4, kol. 232-234; Czyż, Kościół pw. śś. Piotra i Pawta, s. 240.

${ }^{117}$ Wbrew temu co pisze Władysław Tomkiewicz postać św. Tomasza z Canterbury nie została wyeksponowana w obrazie z powodu Tomasza Dolabelli (Tomkiewicz, Obrazy, s. 206), a przez fakt członkostwa w zgromadzeniu kanoników regularnych laterańskich. Postać męczennika, biskupa zabitego przy ołtarzu w 1170 roku była w ich środowisku popularna szczególnie w XVII w. wpisując się w ideę kontrreformacji. 612.

${ }^{118}$ Tomkiewicz, Obrazy, s. 204-207; Moisan-Jabłońska, Obrazowanie walki, s. 564-565, 575,

${ }^{119}$ Na płótnie znajduje się inskrypcja: DUM CHRISTIANI PAUCI NUMERO CUM INGENTI CLASSE TURCARUM NAVALI ATR[O] / CITER DECERTANT, UBIQUE LOCORUM, SED 
Ponad namalowaną bitwą znajduje się emblemat - uskrzydlone pioruny z lemmą „Fortis ultor timor Dei” (Silnym mścicielem jest bojaźń Boża) ${ }^{120}$. Na pierwszym planie przedstawiono procesję, w której biorą udział nie tylko członkowie bractwa ubrani w kaptury i w płaszcze, ale także weneccy dygnitarze łącznie z dożą klęczącym przed ołtarzem. Wśród nich znajdują się także kanonicy regularni. Jest więc to ilustracja Kościoła wojującego, ponad którym widać Kościół Triumfujący. Reprezentuje go Chrystus z rozpostartymi ramionami i Maryja, która ze złożonymi dłońmi dziękuje za zwycięstwo wojsk chrześcijańskich. Obok Zbawiciela znajduje się św. Justyna, patronka Wenecji, której święto przypadało w dzień wiktorii nad muzułmanami ${ }^{121}$.

Trzeci obraz to Msza dziękczynna Piusa V, jedno z najpiękniejszych i najciekawszych ideowo przedstawień liturgii mszalnej w polskim malarstwie nowożytnym ${ }^{122}$. Przed ołtarzem, ponad którym widnienie gorejące serce na patenie z napisem „Deus non est despecies puritas mentis” (Boże nie wzgardź czystością ducha) stoi Pius V oraz akolici z tiarą i ferulą. Ukazane serce, na którym koncentrują się niemal wszystkie spojrzenia osób namalowanych na obrazie ilustruje przyjęcie ofiary składanej podczas liturgii. Za postaciami biorącymi udział w mszy świętej przedstawiono procesję z obrazem Matki Boskiej Śnieżnej. Powyżej ukazano Trójce Świętą wraz z Maryją oraz świętymi, pośród których można rozpoznać św. Dominika, św. Ignacego Loyolę, ale też św. Augustyna oraz kanoników regularnych ${ }^{123}$.

O ile na dwóch wcześniejszych obrazach wykonanych przez Tomasza Dolabellę rysy twarzy były obiegowe, o tyle na tym płótnie postacie wydają się być zindywidualizowane. Oprócz papieża Piusa V można rozpoznać cesarza Maksymiliana II i dowódcę floty spod Lepanto Juana de Austria, a także kanclerza Jana Zamoyskiego, przed którym leżą atrybuty jego godności i urzędu (buława i pie-

MAXIME IN ALMA URBE LAURETI ET VENETIIS TRINUS ET / UNUS INVOCATUR DEUS INVOCATUR ET A DEVOTA CONFRATERNITATAE SANCTISSIMI ROSARII MI / SERICORDIAE MATER, UTPOTE UNICUM POST DEUM, IN TRIBULATIONE CHRISTIANORUM AUXILI [...] NEC TARITATE HUMILIUM PRECES, CONTERITUR ENIM SUPERBUS HOSTIS ANNO CHRI / STIANAE SALUTIS $1571 / /$. Inskrypcja według W. Tomkiewicz, Obrazy, s. 205.

${ }^{120}$ Motyw zaczerpnięty od Tomasza Tretera i jego „Symbolica vitae Christi meditatio”.

${ }^{121}$ Tomkiewicz, Obrazy, s. 207-210. Kościół triumfujący został wydzielony od Kościoła wojującego nie tylko obłokami, ale także przez anioły sypiące kwiaty róży - symboliczne przypomnienie o modlitwie różańcowej. Kobielus, Florarium, s. 184-185, 188-189.

${ }^{122} \mathrm{Na}$ obrazie umieszczono napis: ANNO FORTUNATO 1571 SOLEMNIS GRATIARUM ACTIO PRO INSIGNI VICTORIA, DE SELIMO [TURCO]RUM TYRANO ET IMMANISSIMO CHRISTIANAE FIDEI HOSTE, PER DEI PARAE SANCTISSIMAE INTERCESSIONEM REPO [...], / UT MULTIS DEVOTIS, PRESERTIM PIO V PONTIFICI MAXIMO HAC IPSA DIE, QUA PUGNATUM ET, SACRA CELEBR [...] / REVELATUM FUIT, CUIUS VICTORIAE ET BENEFICI MEMORIA GLORIOSA A CONFRATERNITATE SANCTISSIMI [...] / PRIMUM ROMAE, DEINDE PER TOTUM ORBEM DOM: 1 OCTOBRIS EX INSTITIUTIONE PII V ET GREGORII XII[I] / PLENARIA INDULGENTIA QUOTANNIS SOLENNITER CELEBRATUR, QUOD ET SODALITAS CRASNICEN[SIS] / SANCTISSIMI ROSARII, GRATO RECOLENS ANIMO, IN EIUS MEMORIAM PRENNEHAS IMAGINES [DE] / PINGI CURAVIT ANNO DNI 1626 //. Inskrypcja podana według Tomkiewicz, Obrazy, s. 205.

${ }^{123}$ Tamże, s. 210-212. 
częć). Obok niego klęczą inne postaci niezwiązane z czasami bitwy pod Lepanto, czyli biskup Marcin Szyszkowski oraz starszy lub generał bractwa z umieszczonym na ramieniu emblematem różańcowym. Na tej samej zasadzie na pierwszym planie umieszczono najpewniej wizerunek króla Zygmunta III.

$\mathrm{W}$ ten sposób przedstawiono mszę pontyfikalną, której nadano charakter solemnis gratiarum actio - wielkiej modlitwy dziękczynnej, swoistej missa idealis, która jest odprawiana z udziałem dworów ziemskich papieskiego i cesarskiego, a także dworu niebiańskiego. Ukazując sojusz tiary i korony wokół Eucharystii podkreślono uniwersalizm Kościoła, w czym pomagał także wprowadzony po soborze trydenckim ujednolicony ryt liturgiczny ${ }^{124}$. Według ks. Michała Janochy za pomoca gestów obraz ten wyraża także głęboką ideę potrójnego pośrednictwa: papieża wobec Kościoła, Maryi przed Chrystusem i Chrystusa przed Ojcem ${ }^{125}$.

Podobnie, jak znajdujące się pierwotnie u dominikanów w Poznaniu płótno Bitwa pod Lepanto (obecnie Państwowe Zbiory Sztuki na Wawelu, po 1632 roku) pędzla Tomasza Dolabelli, cykl kraśnicki został wykonany w kontekście zagrożenia tureckiego i zwycięskiej obrony Chocimia. Wizja mocarstw europejskich skupionych wokół Kościoła w walce z muzułmanami nabrała wówczas nowego znaczenia. Poprzez aktualizację podkreślono nieustanną potrzebę modlitw przebłagalnych za grzechy ludzkości, jak i gotowość do stałej obrony świata chrześcijańskiego ${ }^{126}$. Przy czym szczególnie wyeksponowano opiekuńczą rolę Maryi, której powierzają się całe społeczności i państwa. Stawała się ona także patronką walki, którą każdy człowiek prowadzi z szatanem na polu ciała i duszy ${ }^{127}$.

Tematyka maryjna powraca w nawie głównej świątyni, gdzie ponad arkadami znalazły się sceny związane z wcieleniem i dzieciństwem Chrystusa (Zwiastowanie, Nawiedzenie, Pokłon Trzech Króli, Ucieczka do Egiptu) oraz z powołaniem Kościoła i kapłana (Chrystus nauczajacy w światyni, Zesłanie Ducha Świętego) ${ }^{128}$, którym nieprzypadkowo towarzyszą wspomniane postacie dwunastu apostołów.

W myśl zasady pośrednictwa Maryi wobec Syna kanonicy regularni propagowali w swoich świątyniach parę wizerunków: błogosławiącego Zbawiciela Świata i Matkę Boską, jako współuczestniczącą w chwale Chrystusa ${ }^{129}$. Genezą takich

${ }^{124}$ Malarz wybrał moment trwania w kontemplacji. Może to być zarówno czas przed rozpoczęciem ofiarowania jak też dziękczynienia po komunii świętej, na co zdaje się wskazywać kielich przykryty palką i korporałem. Janocha, Missa in arte polona, s. 149.

${ }^{125}$ Tamże, s. 150.

${ }^{126}$ Tomkiewicz, Obrazy, s. 209, 212; Moisan, Matka Boska Różańcowa, s. 93; Janocha, Missa in arte polona, s. 117, 148-150; Moisan-Jabłońska, Obrazowanie walki, s. 241-244, 324-328, 576. Fundatorem obrazów dla bractwa różańcowego był Tomasz Zamoyski, który przy okazji przypomnienia o potrzebie modlitwy zawarł także swoje polityczne credo. Jako spadkobierca Jana Zamojskiego był jednocześnie kontynuatorem ambicji politycznych ojca realizowanych w ścisłym związ$\mathrm{ku} \mathrm{z}$ dworem królewskim. Była to także jasna deklaracja wobec zabiegów związanych z obroną kraju. Poprzez ukazanie procesji różańcowej w Wenecji podkreślił także swoje związki polityczne i kulturowe z Serenissima.

${ }^{127}$ Moisan-Jabłońska, Obrazowanie walki, s. 29-161, 278-306.

${ }^{128}$ Malowidła nie zostały przy tym ułożone chronologicznie. Od południa znajduje się: Zwiastowanie, Zesłanie Ducha Świętego i Nawiedzenie, a od północy: Pokłon trzech króli, Ucieczka do Egiptu, Chrystus nauczajacy.

${ }^{129}$ Para ołtarzy z wizerunkami Salvatora Mundi i Mater Misericordiae znajdują się w kościele 
przedstawień jest przekonanie o compassio i corredemptio, przez co Maryja została wyniesiona do godności porównywalnej z wielkością jej Syna. W ten sposób stała się ona nie tylko Mater Dolorosa, ale Mater Misericordiae. W przedstawieniach takich Bogurodzica całą swą postawą wyraża poddanie się woli Bożej, akceptuje jej przyjęcie i jest nią wypełniona. Niepokalaną pokorę i czystość wyraża opuszczenie głowy i dłonie składane na piersiach. Chrystus, do którego Maryja prowadzi wiernego to Salvator $M u d n i^{130}$, przez kanoników regularnych laterańskich postrzegany jako pierwszy przeor Ordo apostolicus ${ }^{131}$.

\section{Podsumowanie}

Nowożytne wyposażenie kościoła pw. Wniebowzięcia Najświętszej Maryi Panny i św. Augustyna w Kraśniku powstało w przeciągu trzystu lat. Jednak najstarsze ślady wystroju pochodzące z XVI w. są niezwykle skromne. Jeszcze w pierwszej połowie XVII w. uległy one wymianie, a stało się to w momencie przystąpienia klasztoru w Kraśniku do kongregacji krakowskiej. Szczególne znaczenie w kreowaniu nowego wystroju świątyni miały lata 30. XVII, kiedy ufundowano stalle, w tym także kolatorskie, obrazy Dolabelli, a także ołtarz główny i bracki. To na nich oparto najważniejsze elementy wątków treściowych: kanonickiego (Ordo apostolicus, patroni kongregacji krakowskiej), pasyjno-eucharystycznego, maryjnego (w tym Salvator Mundi i Mater Misericordiae), a także patronackiego. Nie można wykluczyć, że intensywne inwestycje artystyczne wiązały się z planem zwołania do Kraśnika kapituły generalnej w 1635 roku. W kolejnych dekadach, a szczególnie w latach przypadających na połowę XVIII w. przez fundacje nowych ołtarzy i ambony oraz malowideł w prezbiterium wystrój w zarysowanych wcześniej ramach treściowych był uzupełniany i rozwijany.

Porównując pojawiające się wątki w dekoracji kościoła w Kraśniku z innymi świątyniami kanoników regularnych kongregacji krakowskiej należy stwierdzić, że są one typowe. Odwołano się w nich do specyfiki zakonnej, w tym duchowości

pw. Bożego Ciała w Krakowie. Obrazy w latach 1623-1625 namalował Łukasz Porębski według grafik Antoniego Wierixa z ok. 1580 roku. Ciekawym dziełem sztuki powstałym w środowisku kanoników regularnych jest monstrancja (1720-1740) z kościoła pw. Bożego Ciała w Krzemienicy, gdzie na stopie znajduje się przedstawienie Salvator Mundi i Maria Misericordiae. W kościele tym zachował się także obraz Matki Boskiej (do 1657) w tym typie umieszczony w ołtarzu bocznym. D. Piramidowicz, Kościót pw. Bożego Ciała i klasztor Kanoników Regularnych Laterańskich w Krzemienicy, w: Kościoły i klasztory rzymskokatolickie dawnego województwa nowogródzkiego, red. M. Kałamajska-Saeed, Kraków 2006, t. 2, s. 42, 45, 58. Zob. także Krasnowolski, Zapomniane sanktuarium, s. 129.

${ }^{130}$ Kraśnicki obraz Zbawiciela Świata został namalowany w warsztacie wziętego malarza weneckiego Parisa Borodone. Biorąc pod uwagę kontakty Zamoyskich z Serrenissima wśród nich winno się poszukiwać ofiarodawcy. Być może obraz znalazł się w Rzeczpospolitej jeszcze w czasach Jana Zamoyskiego. W związku z tym, że architektura tła obrazu jest wzorowana na rysunku kapitela kompozytowego z Porta dei Borsari w Weronie opublikowanego w III księdze Sebastiana Serlia płótno z Kraśnika należy datować na lata 1540-1571. Kaleciński, Muta praedicatio, s. 67-69, 85. Obraz Maryi powstał zapewne w latach 30. XVII w., ołtarz jest późniejszy, konsekrowany w 1762 roku.

${ }^{131}$ Stąd wziął się jego wizerunek na zapleckach tronu prepozyta w kościele pw. Bożego Ciała w Krakowie. Krasnowolski, Zapomniane sanktuarium, s. 131. 
kanonickiej i „pierwszeństwa” zgromadzenia oraz posługi duszpasterskiej rozwijanej w oparciu o treści pasyjno-eucharystyczne i maryjne. Prezentowano je w kontekście przemian zachodzących w życiu Kościoła po Soborze Trydenckim, w nurt których weszła także kongregacja krakowska Bożego Ciała współkreując nowy model sztuki sakralnej w Rzeczpospolitej.

słowa kluczowe: kościół; ikonografia; wystrój kościoła; kanonicy regularni; Kraśnik

\section{BIBLIOGRAFIA}

\section{Źródla}

Archiwum Kurii Metropolitalnej w Krakowie sygn.: AV t. 12; AV t. 45; AV Cap. t. 66.

Possydiusz z Kalamy, Żywot św. Augustyna, tłum. P. Nehring, Kraków 2002.

Św. Augustyn, Wyznania, Kraków 1996.

Św. Augustyn, Pisma monastyczne, thum. P. Nehring, M. Starowieyski, R. Szaszka, Kraków 2002.

\section{Opracowania}

Bania Z., Architektura kościołów kanoników regularnych laterańskich ze szczególnym uwzględnieniem kongregacji Bożego Ciała na Kazimierzu w Krakowie, w: Przemijanie i trwanie. Kanonicy regularni laterańscy $w$ dawnej $i$ wspótczesnej Polsce. Materiaty z międzynarodowej konferencji zorganizowanej z okazji 600-lecia fundacji opactwa Bożego Ciała w Krakowie, Kraków 2005, s. 59-66.

Brykowska M., Architektura karmelitów bosych w XVII-XVIII wieku, Warszawa 1991. Czyż A. S., Kościót pw. śś. Piotra i Pawta na Antokolu w Wilnie, Wrocław-Warszawa-Kraków 2008.

Drączkowski F., Gelazy I, w: Encyklopedia Katolicka, t. 5, Lublin 1989, kol. 932;

Drączkowski F., Klemens Aleksandryjski, w: Encyklopedia Katolicka, t. 9, Lublin 2002, kol. 98-102.

Dzik J., Ikonografia Stanisława Kazimierczyka jako reprezentanta światobliwych „,Felicis Saeculi Cracoviae” w polskiej sztuce nowożytnej, „Nasza Przeszłość”, 68 (1987) s. 61-91.

Dzik J., Przyczynek do mecenatu artystycznego Kościoła w XVII wieku, „Nasza Przeszłość", 75 (1991) s. 329-342.

Fros H., Sowa F., Księga imion i świętych, Kraków 2000.

Gospodarz Nieba i Ziemie, Jezus Chrystus, Syn Bozy, Bóg wcielony, Zbawiciel i Naprawca Świata w przednie Tajemnic i dziet swoich uroczystości, Pobożnemu Auditorowi na kazaniach wystawiony, od X. Jacka Liberiusza S. T. Doktora Proboszcza kośćioła Bożego Ciała na Kazmierzu przy Krakowie. W Kazimierzu przy Krakowie w Drukarni Balcera Smieszkowicza Typ. R. P. 1665.

Guttmejer K., Siedemnastowieczne fundacje dla kamedułów w Polsce, w: Studia nad sztukq renesansu i baroku, t. 8, cz. 3: Fundator i dzieło w sztuce nowożytnej, red. J. Lileyko, I. Rolska-Boruch, Lublin 2007, s. 55-105. 
Jakubowski Z., Madonna z Dzieciatkiem w krakowskim klasztorze kanoników regularnych - dzieło Lukasza Cranacha st., „Biuletyn Historii Sztuki”, 39 (1977) z 2, s. 127-142.

Janocha M., Missa in arte polona. Ikonografia mszy świętej w średniowiecznej i nowożytnej sztuce polskiej, Warszawa 1998.

Joannis de Nigra Valle, Ord. praemonstratensis, S. R. E. Bibliothccarius In Sacri et Apostolici ordinis Canonicorum Regularium S. Augustini Congregationis S. Salvatoris, Lateranensis Genealogiam quam plurimis, iisq; gravissimis et quidem externorum authoritatibus, dilucidatus. Et per Canonicos Congregationis Cracoviensis ejusdem Instituti, vitae sanctitate, status eminentia, et doctrinae, soliditate insignes, ampliatus. Tum etiam accomodatissimis suo assumpto el intentioni Regularis Lateranensis, Schematibus exorantus nec non labore ac studio A. R. D. Aquilini Michaelis Gorczyński J. C. et S. Th. D. Canonici Regularis Laterasnensis Luci publicae reostensus. Anno Domini 1707 [bez m. dr.].

Jurkowlaniec G., Epoka nowożytna wobec średniowiecza. Pamiątki przeszłości, cudowne wizerunki, dzieła sztuki, Wrocław 2008.

Kaleciński M., Muta praedicatio. Studia z historii i recepcji malarstwa włoskiego doby potrydenckiej, Warszawa 1999.

Karpińska, Z kart historii miasta i kościoła, w: Kościół Wniebowzięcia Najświętszej Maryi Panny w Kraśniku, Kraśnik 2013.

Katalog zabytków sztuki w Polsce, t. 8: Województwo lubelskie, red. R Brykowski, E. Smulikowska, Z. Winiarz, z. 9: Powiat kraśnicki, oprac. J. Galicka, E. Smulikowska, Warszawa 1961.

Klasztor Bożego Ciała Kanoników Regularnych Laterańskich w Krakowie w okresie przedtrydenckim. Ludzie-wydarzenia-budowle-kultura, red. K. Łatak, Łomianki 2012.

Knapiński R., Credo Apostolorum w średniowiecznej i nowożytnej ikonografii kościelnej, w: Symbol Apostolski w nauczaniu i sztuce Kościoła do soboru trydenckiego, red. R. Knapiński, Lublin 1997.

Knipping J.B., Iconography of the Counter Reformation in the Netherlands. Heaven on Earth, t. 1, Nieuwkoop-Leiden 1974.

Kobielus S. , Bestriarium chrześcijańskie. Zwierzęta w symbolice i interpretacji. Starożytność i średniowiecze, Warszawa 2002.

Kobielus S., Concordia Novi et Veteris Testamenti. Zapowiedzi dzieła odkupienia i jego spetnienie w teologii i sztuce średniowiecza, Poznań 2013.

Kobielus S., Floralium christianum. Symbolika roślin-chrześcijańska starożytność i średniowiecze, Tyniec 2006.

Kobielus S., Krzyż Chrystusa. Od znaku i figury do symbolu i metafory, Warszawa 2000.

Kornecki M., Matka Boska Polska. Adaptacja i rozpowszechnienie typu ikonograficznego obrazu Matki Boskiej Śnieżnej od XVI do XVIII wieku, w: Dzieje Lubelszczyzny, t. 6 cz. 3 Kultura artystyczna, red. T. Chrzanowski, Lublin 1992.

Korolec J.B., Biblioteki Lubelszczyzny w XV-XVIII wieku (Biblioteka Kanoników Regularnych w Kraśniku), w: Dzieje Lubelszczyzny, t. 6: Między Wschodem a Zachodem, cz. 1: Kultura umystowa, red. J. Kłoczowski, Warszawa 1989.

Kowalczyk J., Koronacja Najświętszej Maryi Panny w Kraśniku - dzieło Jana Kasińskiego, „Roczniki Humanistyczne”, 42 (1994).

Krasnowolski B., Zapomniane sanktuarium maryjne i laterańskie z 1 połowy XVII wieku w Suchej. Wielka treść w skromnej formie, w: Festina lente. Prace ofiarowane Andrzejowi Fischingerowi w siedemdziesiąta rocznicę urodzin, Kraków 1998, s. 127-138.

Krasnowolski B., Średniowieczne wnętrze kościoła Bożego Ciała w świetle kroniki ks. Stefana Ranatowicza CRL, w: Klasztor Bożego Ciała Kanoników Regularnych Laterań- 
skich $w$ Krakowie $w$ okresie przedtrydenckim. Ludzie-wydarzenia-budowle-kultura, red. K. Łatak, Łomianki 2012, s. 269-284.

Krasny P., Visibilia signa ad pietatem excitantes. Teoria sztuki sakralnej $w$ pismach Roberta Bellarmina, Cezarego Baroniusza, Rudolfa Hospiniana, Fryderyka Boromeusza i innych pisarzy kościelnych epoki nowożytnej, Kraków 2010, s. 8-9.

Krótka nauka o czci i poszanowaniu obrazów Swiętych, przydane opisanie obrazu Najśw. P. Maryi w kaplicy kościoła Ciała Bożego Wielebnych Ojców Kanoników laterańskich Augustyna S. na Kazimierzu przy Krakowie .... przez W. X. Jana Augustyna Biesiekierskiego Kanonika laterańskiego S. Augustyna Zakonu. Za dozwoleniem Starszych. W Krakowie w Drukarni Macieja Andrzejowczyka R. P. 1624.

Kuczman K., Italianizujące „Opłakiwanie Chrystusa” z roku 1519 w krakowskim klasztorze kanoników regularnych, „Biuletyn Historii Sztuki”, 40 (1978) z. 2, s. 104-117.

Moisan-Jabłońska K., Obrazowanie walki dobra ze złem, Kraków 2002.

Moisan K.S., Matka Boska Pocieszenia, w: Maryja orędowniczka wiernych, red. J.S. Pasierb, Warszawa 1987.

Nowacki D., W sprawie kondycji badań nad tekstyliami w zbiorach krakowskich. Kapa w kościele Bożego Ciała - niedoceniony świadek potrydenckich przeobrażeń kazimierskiej fary, w: Tekstylia w zbiorach sakralnych. Inwentaryzacja - konserwacjaprzechowywanie, red. H. Hryszko, A. Kwaśnik-Gliwińska, M. Stachurska, Warszawa 2013, s. 165-173.

Nowiński J., Ars cisterciensis. Kościól cysterski w średniowieczu-wyposażenie i wystrój, Warszawa 2016.

Pasierb J. S., Problematyka sztuki w postanowieniach soborów, „Znak”, 12 (1964) t. 16, s. $1462-1471$.

Ripa C., Iconologia, Kraków 2002.

Rupiewicz R., Pierwowzory graficzne wizerunku „Sąd nad Chrystusem” z kościoła Bożego Ciała w Krakowie, w: Inspiracje grafika europejska w sztuce nowożytnej. Czasy nowożytne, red. K. Moisan-Jabłońska, K. Ponińska, Warszawa 2010, s. 58-78.

Rupiewicz R., Sensacyjne odkrycia wyroków Piłata w XVI stuleciu. Jego źródła i oddziaływanie, w: Apud Patres. Prawo rzymskie w literaturze wczesnochrześcijańskiej, red. A. Dębiński, M. Wójcik, Lublin 2011.

Siodłowska M., Patryk, w: Encyklopedia Katolicka, t. 15, Lublin 2011, kol. 63-64.

Studia z dziejów kościoła Bożego Ciała w Krakowie, red. Z. Jakubowski, Kraków 1977.

Szymusiak J.M., Starowieyski M., Słownik wczesnochrześcijańskiego piśmiennictwa, Poznań 1971.

Tomkiewicz W., Uchwała synodu krakowskiego z 1621 roku o malarstwie sakralnym, „Sztuka i krytyka”, 8 (1957) s. 174-184.

Wardzyński M., Ze studiów nad snycerstwem krakowskim i małopolskim około roku 1630, w: Studia nad sztuka renesansu i baroku, red. J. Lileyko, I. Rolska-Boruch, t. 5, Lublin 2004.

Wojtyska H.D., Czytelnictwo i biblioteki u kanoników regularnych laterańskich kongregacji Bożego Ciała, w: Kanonicy regularni laterańscy $w$ Polsce. Studia z dziejów kongregacji krakowskiej XV-XIX w., red. Z. Jakubowski, Kraków 1975, s. 54, 56-57.

Wojtyska H. D., Duchowość kanoników regularnych, „Saeculum Christianum”, 3 (1996) z. 3.

Wojtyska H.D., Nauka i nauczanie u kanoników regularnych (na przykładzie Kongregacji Bożego Ciała), w: Dzieje teologii katolickiej w Polsce, t. 2., z. 2, red. M. Rechowicz, Lublin 1975.

Wysocki M., Roman z Cezarei, „Encyklopedia Katolicka”, t. 17, Lublin 2012, kol. 258. 
Zapolska E., Cnoty teologalne i kardynalne, Kraków 2000.

Łatak K., Kanonicy regularni laterańscy na Kazimierzu w Krakowie do końca XVI wieku, Ełk 1999.

Łatak K., Kongregacja krakowska kanoników laterańskich na przestrzeni dziejów, Kraków 2002.

Łatak K., Madonna z jabłuszkiem (Mater Salvatoris) w krakowskim kościele Bożego Ciata, w: Homo Creator et Receptor Artium. Księga pamiatkowa Księdzu Profesorowi Stanisławowi Kobielusowi ofiarowana, red. M. Wrześniak, Warszawa 2010, s. 153164.

Łatak K., Nalbach S., Ze studiów nad kultura umysłowa kanoników regularnych laterańskich krakowskiej prepozytury Bożego Ciała w XV i XVI wieku, Kraków 2009.

Łatak K., Z dziejów obrazu Madonny Roudnickiej w krakowskim kościele pw. Bożego Ciata, w: Architektura znaczeń. Studia ofiarowane prof. Zbigniewowi Bani w 65. rocznice urodzin i w 40-lecie pracy dydaktycznej, red. A.S. Czyż, J. Nowiński, M. Wiraszka, Warszawa 2011, s. 240-251.

Święty Stanisław Kazimierczyk CRL (1433-1489). Postać - środowisko - kultura - dziedzictwo, red. K. Łatak, Kraków 2010.

Żywot, sprawy y cudowne Boskie wstawienie pobożnego Kapłana B. Stanisława Kazimirczyka, przy Krakowie na Kazimirzu u Bożego Ciała, Congrcgacyey Zbawicielowey: Kanoników z Literanu wedtug Reguty S. Angustyna ... Ku chwale Bożey y czci Świętych iego ... dopiro teraz Polskim ięzykiem napisany, dostateczniey y własniey nizeli byt przed tym po Łacinie wydany w roku 1609 przez X. Krzysztofa Łoniewskiego, tegoż Conwentu Kanonika. Z dozwoleniem Starszych. W Krakowie, w drukarniey Łazarzowey, Maciey Jędrzeiowczyk drukowat Roku P. 1617.

Żywy wzór Apostolskiea doskonatości, B. Stanisław Kazimierczyk, w sławnej Akademiej Krakowskiej Profesor, i S. Teologiej Bakałarz, Zakonu Canonicor. Regular. S. Salvatoris Lateran.Theolog i Przeor ... Przez X. Aquilina Michała Gorczyńskiego Prawa Duchownego i Pisma S. Doktora i Profesora, S. Stolice Apostolskiei Pisarza, tegoż Zakonu i u Bożego Ciała na Kazimierzu Kanonika światu wystawiony. Roku 1702 w Krakowie w drukarni Akademickiej. 


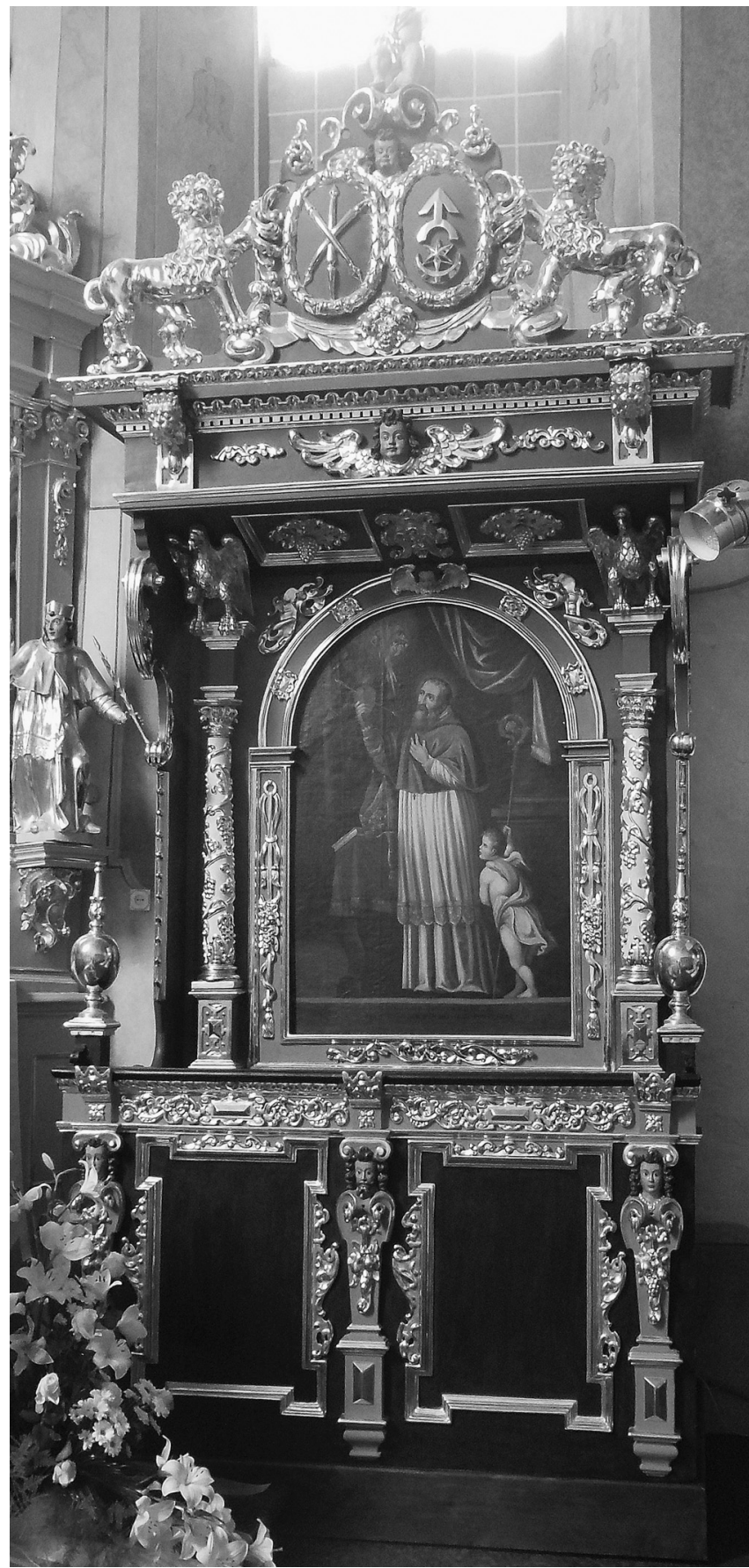

Il. 1. Stalle kolatorskie Tomasza Zamoyskiego i Katarzyny z Ostrogskich z wyobrażeniem św. Augustyna przed Świętą Trójcą, lata 30. XVII w. Fot. Anna S. Czyż 


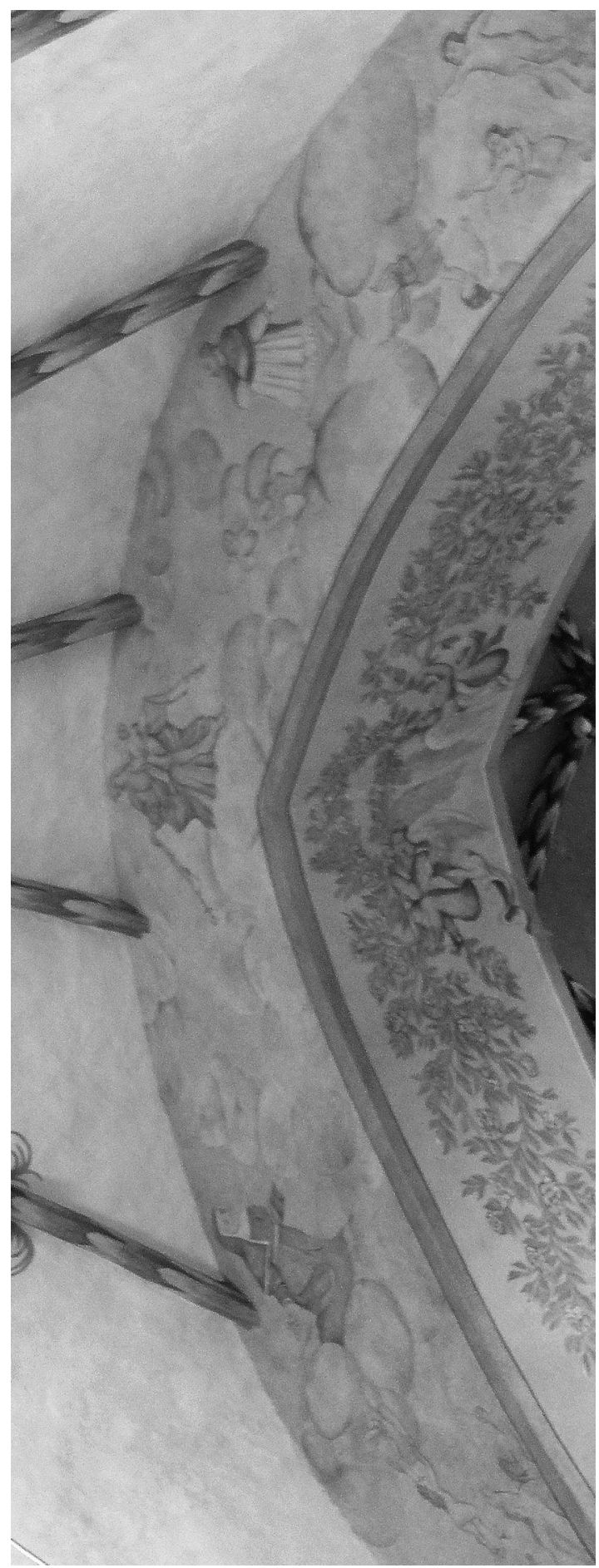

Il. 2. Matka Boska Pocieszenia, malowidło na łuku tęczowym od strony prezbiterium, XVIII w. Fot. Anna S. Czyż 


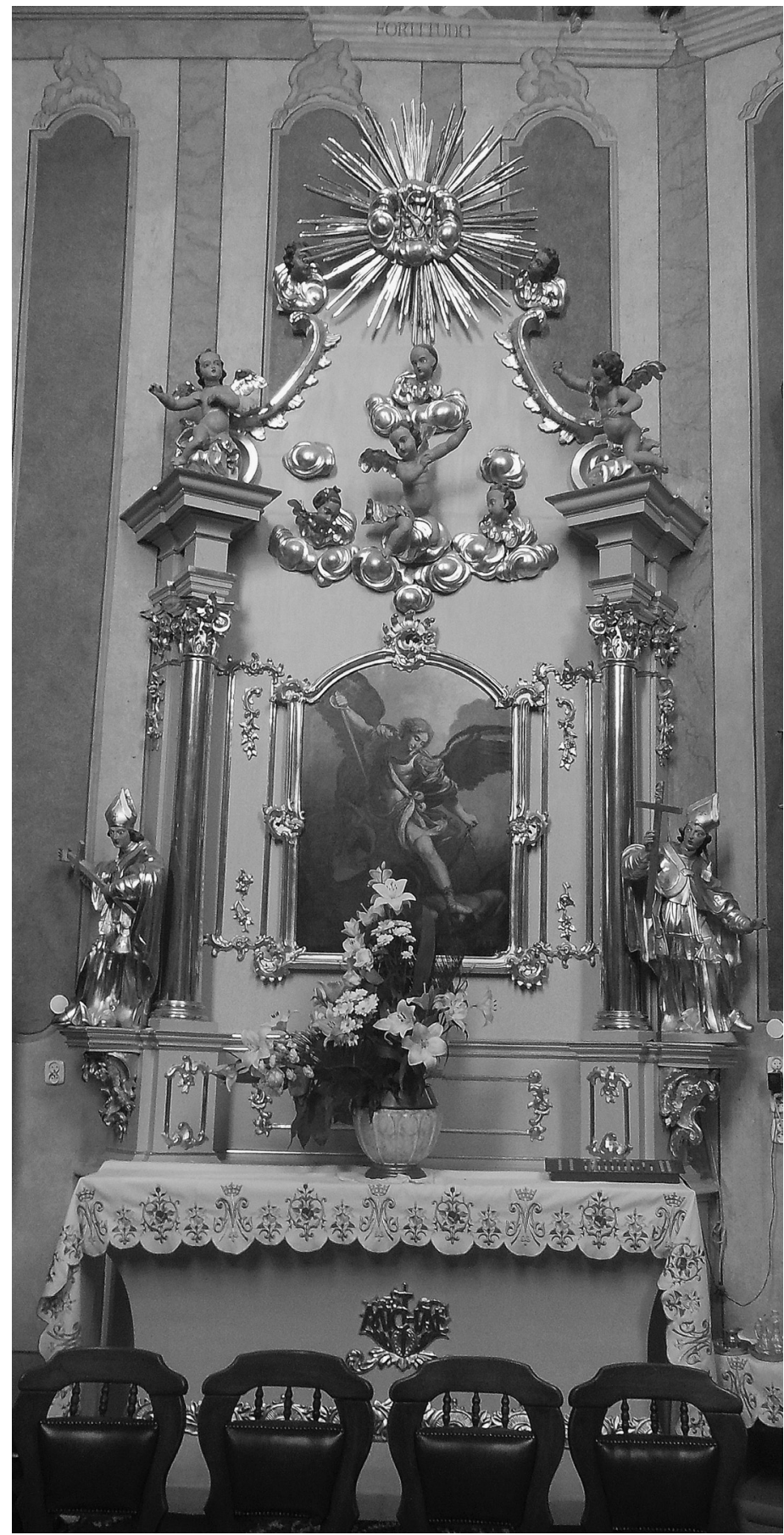

I1. 3. Ołtarz Michała Archanioła w prezbiterium świątyni, przed 1762. Fot. Anna S. Czyż 


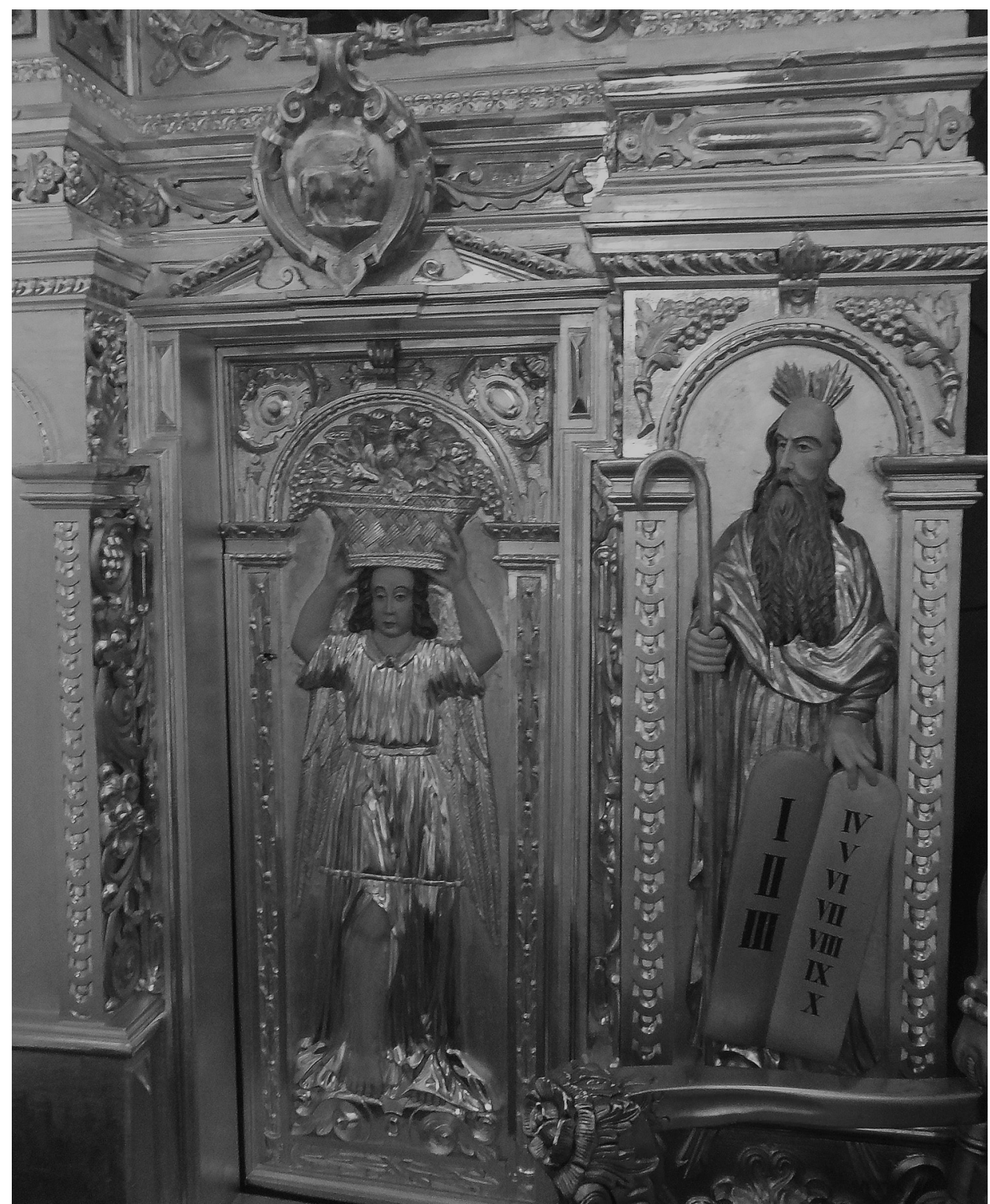

Il. 4. Fragment dekoracji ołtarza głównego z aniołem z koszem kwiatów i postacią Mojżesza, ok. 1630. Fot. Anna S. Czyż 


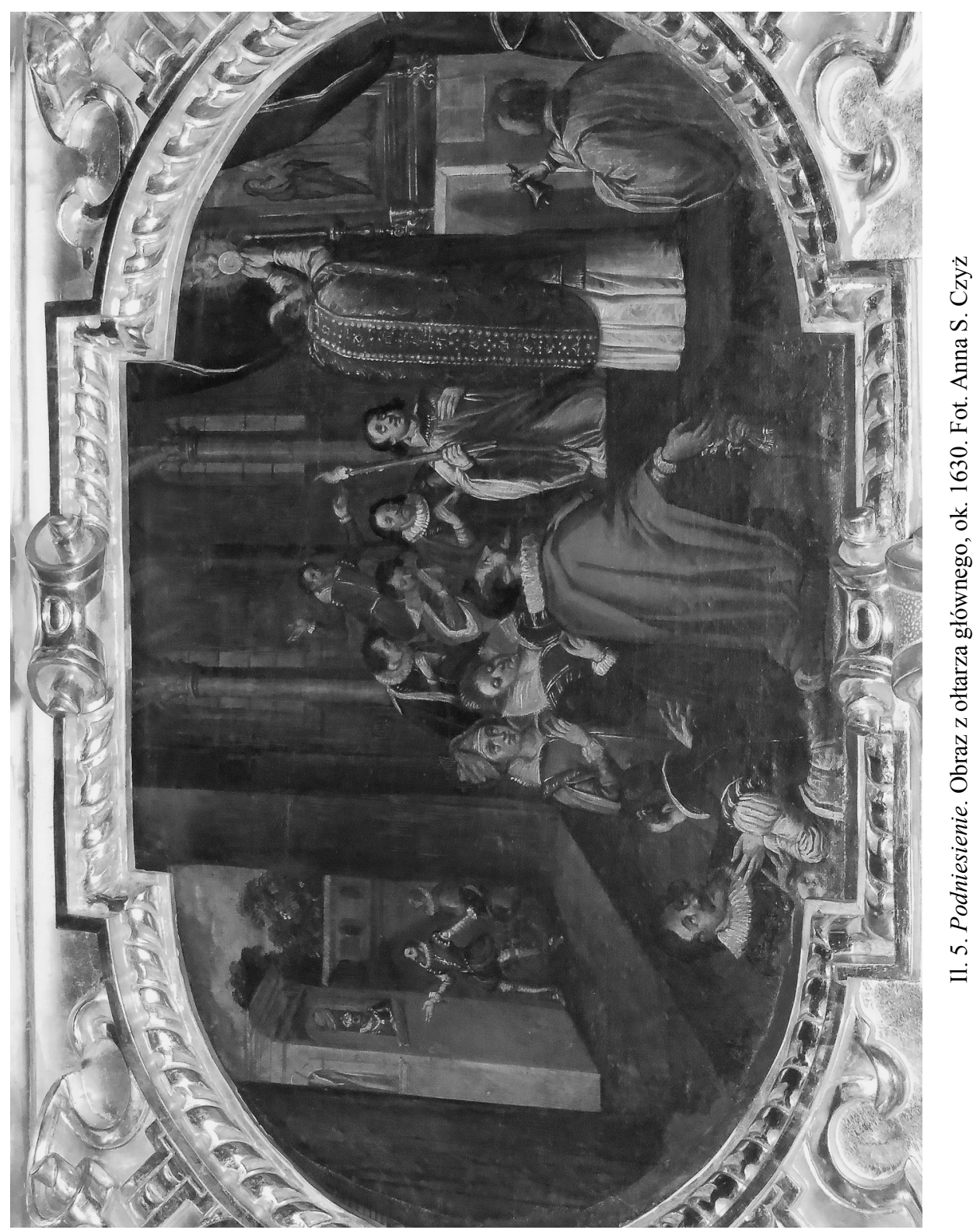




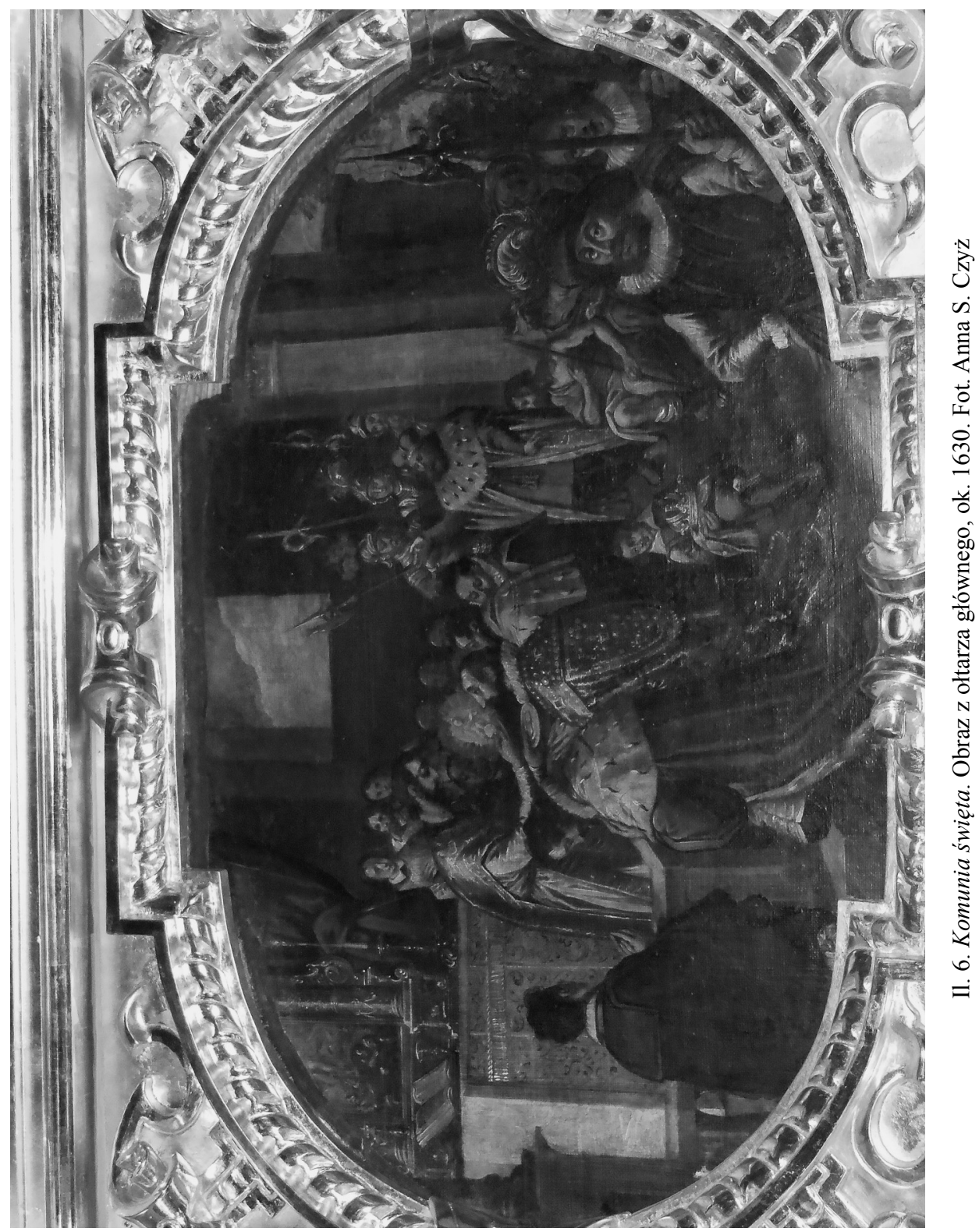




\title{
ICONOGRAPHY OF THE INTERIOR OF THE CHURCH DEDICATED TO THE ASSUMPTION OF THE BLESSED VIRGIN MARY AND ST. AUGUSTINE IN KRAŚNIK (17TH AND 18TH CENTURIES)
}

\begin{abstract}
Summary
Modern furnishings of the church dedicated to the Assumption of the Blessed Virgin Mary and St. Augustine in Kraśnik were created over three hundred years. However, the oldest trace of the decor from the 16th century is scant. In the first half of the 17th century they were exchanged, and it was at the time when the monastery in Kraśnik joined the Cracow Congregation. The 1630s were particularly important in the creation of the new decor of the church as the following things were founded: choir stalls, including collator ones, paintings by Dolabella as well as the high altar and brotherhood's one. The above-mentioned elements of the interior were means of conveying the most important themes: canonic (Ordo apostolicus, the patrons of the Cracow Congregation), Passion, Eucharistic, Marian (including SalvatorMundi and MaterMisericordiae) as well as patronal. It cannot be ruled out that intensive artistic investment was connected with the plan to convene the General Chapter in Kraśnik in 1635. In the following decades, especially in the mid-eighteenth centuries, the interior was supplemented and developed, within the aforementioned themes, through the foundations of new altars, a pulpit and paintings in the chancel.

Comparing the themes of the church decoration in Krasnik with other churches of the Canons Regular of the Cracow Congregation, it should be noted that they are typical. They referred to monastic life, including the spirituality of the canons and the ,primacy" of the congregation, as well as the pastoral ministry being developed on the basis of Passion, Eucharistic and Marian themes. They were presented in the context of the changes taking place in the life of the Church after the Council of Trent, the trend which was also adopted by the Cracow Congregation of Corpus Christi, which co-created a new model of the sacred art in the Republic of Poland.
\end{abstract}

Keywords: a church; iconography; church decor; the Canons Regular; Kraśnik 